\title{
Diabetic foot ulcer: A review
}

\author{
Mohammad Zubair ${ }^{1}$, Abida Malik², Jamal Ahmad ${ }^{1}$ \\ ${ }^{1}$ Rajiv Gandhi Centre for Diabetes and Endocrinology, Faculty of Medicine, Aligarh Muslim University, Aligarh 202002, India \\ ${ }^{2}$ Department of Microbiology, Faculty of Medicine, Aligarh Muslim University, Aligarh, India
}

Email address:

mohammad_zubair@yahoo.co.in (M. Zubair)

\section{To cite this article:}

Mohammad Zubair, Abida Malik, Jamal Ahmad. Diabetic Foot Ulcer: A Review. American Journal of Internal Medicine. Vol. 3, No. 2, 2015, pp. 28-49. doi: 10.11648/j.ajim.20150302.11

\begin{abstract}
Diabetic foot problems are common throughout the world, resulting in major medical, social and economic consequences for the patients, their families, and society. Foot ulcers are more likely to be of neuropathic origin, and therefore eminently preventable. People at greatest risk of ulceration can easily be identified by careful clinical examination of the feet: education and frequent follow-up. Infection when complicates a foot ulcer, combination can be limb or life-threatening, and infection is defined clinically, but wound cultures assist in identifying the causative pathogens. Tissue specimens are strongly preferred to wound swabs for wound cultures. Antimicrobial therapy should be guided by culture results, and although such therapy may cure the infection, it does not heal the wound. Alleviation of the mechanical load on ulcers (offloading) should always be a part of treatment. Plantar neuropathic ulcers typically heal in 6 weeks with irremovable casting, because pressure at the ulcer site is mitigated and compliance is enforced. The success of other approaches to offloading similarly depends on the patients' adherence to the effectiveness of pressure relief.
\end{abstract}

Keywords: Diabetic Foot, India

\section{Introduction}

All forms of diabetes, both inherited and acquired, are characterized by hyperglycemia, a relative or absolute lack of insulin, and the development of diabetes specific micro-vascular pathology in the retina, renal capillaries and peripheral nerves. Diabetes is also associated with premature and accelerated atherosclerotic macro-vascular disease affecting arteries that supply the heart, brain, and lower extremities. Pathologically, this condition resembles microvascular disease in non-diabetic patients, but it is more extensive and progresses more rapidly in diabetic subjects. As a consequence of the micro-vascular pathology, diabetes mellitus is now the leading cause of new blindness in people with 20 to 74 years of age and end-stage-renal-disease (ESRD). People with diabetes mellitus are the fastest growing group of renal dialysis and transplant recipients. The life expectancy of patients with diabetic ESRD is only 3 to 4 years.

More than $60 \%$ of diabetic patients are affected by neuropathy, which include distal symmetrical polyneuropathy (DSPN), mono-neuropathies, and a variety of autonomic neuropathies causing erectile dysfunction, urinary incontinence, gastroparesis, and nocturnal diarrhoea.
Accelerated lower extremity arterial disease in conjunction with neuropathy makes diabetes mellitus accounting for $\sim 50 \%$ of all non-traumatic amputations globally. The risk of cardiovascular complications is increased by two-fold to six-fold in subjects with diabetes. Overall, the life expectancy is about 7 to 10 years shorter than for peoples without diabetes mellitus because of increased mortality from diabetic complications. Large prospective clinical studies show a strong relationship between glycemia and diabetic microvascular complications in both type 1 diabetes and type 2 diabetes [1,2]. There is a continuous, not linear, relationship between level of glycemia and the risk of development and progression of these complications.

\section{Epidemiology of Diabetes Mellitus}

\subsection{World Scenario}

Diabetes mellitus is one of the most common chronic diseases in nearly all countries, and its prevalence is on increase as changing lifestyles lead to reduce physical activity, and increased obesity. It was described as the "global 
epidemic" of the 21st century; the increasing incidence of diabetes will place considerable strain on resources and will bring suffering to many, if the preventive measures are not put into effect. There have been several previous estimates of the prevalence of diabetes [3-6]. The World Health Organization (WHO) estimated that in the year 2000, roughly 3\% of the total world population had diabetes (these results include type 1 and type 2, but not gestational diabetes) [7]. WHO also estimated for the years 2000 and 2030, using data from 40 countries but extrapolated to the 191 WHO member states only [6]. Other estimate has been produced by the International Diabetes Federation (IDF) [8,9]. The latest estimates of the prevalence of diabetes in the year 2010 by Whiting et al., [10] were the data from all the 216 countries of the United Nations. They considered only 91 countries, in which prevalence studies have been undertaken, 5 of the 10 world's highest national prevalence occurred in the
Middle-East (Table 1), although only Saudi Arabia (18.7\%) is among the 80 most populous countries. The Gulf States have prevalence similar to that of Saudi Arabia, and 20 of the 22 Earthquake Model of the Middle East (EMME) regional countries have prevalence above the world 2010 prevalence of $6.4 \%$.

In developing countries, the majority of people with diabetes are in the 45 to 64 year age range [5]. In contrast, in developed countries, it was $>64$ years of age. By 2030, it is estimated that the number of people with diabetes $>64$ years of age will be $>82$ million in developing countries and $>48$ million in developed countries. In the current estimates, on the advice of local experts, the prevalence of diabetes in rural areas is assumed to be one-quarter that of urban areas for Bangladesh, Bhutan, India, the Maldives, Nepal, and Sri Lanka [11].

Table 1. Top 10 countries for diabetes prevalence in 2010 and 2030 [21].

\begin{tabular}{lllll}
\hline & $\mathbf{2 0 1 0}$ & & $\mathbf{2 0 3 0}$ \\
\cline { 2 - 5 } & Country & Prevalence (\%) & Country & Prevalence (\%) \\
\hline 1 & Nauru & 30.9 & Nauru & 33.4 \\
2 & United Arab Emirates & 18.7 & United Arab Emirates & 21.4 \\
3 & Saudi Arabia & 16.8 & Saudi Arabia & 19.8 \\
4 & Mauritius & 16.2 & Mauritius & 18.9 \\
5 & Bahrain & 15.4 & Bahrain & 18.1 \\
6 & Reunion & 15.3 & Reunion & 17.3 \\
7 & Kuwait & 14.6 & Kuwait & 16.9 \\
8 & Oman & 13.4 & Oman & 15.7 \\
9 & Tongo & 13.4 & Tongo & 14.9 \\
10 & Malaysia & 11.6 & Malaysia & 13.8 \\
\hline
\end{tabular}

Only includes countries where surveys with blood glucose were undertaken for that country

Table 2. Top 10 countries for numbers of people aged 20-79 years with diabetes in 2010 and 2030 [21].

\begin{tabular}{lllll}
\hline & $\mathbf{2 0 1 0}$ & & 2030 & \\
\cline { 2 - 5 } & Country & No. of adults with Diabetes (millions) & Country & No. of adults with Diabetes (millions) \\
\hline 1 & India & 50.8 & India & 87.0 \\
2 & China & 43.2 & China & 62.6 \\
3 & USA & 26.8 & USA & 36.0 \\
4 & Russian Federation & 9.6 & Russian Federation & 13.8 \\
5 & Brazil & 7.6 & Brazil & 12.7 \\
6 & Germany & 7.5 & Germany & 12.0 \\
7 & Pakistan & 7.1 & Pakistan & 11.9 \\
8 & Japan & 7.1 & Japan & 10.4 \\
9 & Indonesia & 7.0 & Indonesia & 10.3 \\
10 & Mexico & 6.8 & Mexico & 8.6 \\
\hline
\end{tabular}

\subsection{Indian Scenario}

The first national study on the prevalence of type 2 diabetes in India was done between 1972 and 1975 by the Indian Council Medical Research (ICMR-New Delhi) [12, 13]. A National Rural Diabetes Survey was done between 1989 and 1991 in different parts of the country's rural populations which showed diabetic prevalence as 2.8 per cent [14]. The prevalence of 6.1 percent in individuals aged above 40 years was unexpectedly high at that time for rural area with low socio-economic status and decreased health awareness [15]. In Kashmir vally, a cross-sectional population survey was done in 2000 and the prevalence of 'known diabetes' was 1.9 per cent among adults aged $>40$ years [16].
In The National Urban Diabetes Survey (NUDS), a population based study was conducted in six metropolitan (Delhi, Mumbai, Kolkata, Chennai, Hyderabad, Bangalore) cities across India and recruited 11,216 subjects aged 20 years and above, representative of all socio-economic strata [17]. This study reported the age standardized prevalence of type 2 diabetes as 12.1 per cent. Another study conducted in western India showed age-standardized prevalence of 8.6 per cent in urban population [18]. The Amrita Diabetes and Endocrine Population Survey (ADEPS) [19], a community based cross-sectional survey done in urban areas of Ernakulum district in Kerala has revealed a very high prevalence of 19.5 per cent. 
Prevalence of Diabetes in India Study (PODIS). A multicentric cross sectional population survey was undertaken to determine the prevalence of diabetes mellitus and impaired glucose tolerance in subjects aged 25 years and above in 77 centres (40 urban and 37 rural) across India . A total of 18363 (9008 males and 9355 females) subjects were studied. 10617 (5379 males and 5238 females) were from urban areas and 7746 (3629 males and 4117 females) from rural areas. The prevalence rate for DM in the total Indian, urban and rural populations was $4.3,5.9$ and $2.7 \%$, respectively. The corresponding IGT rates in the three populations were 5.2, 6.3 and $3.7 \%$, respectively. The urban prevalence of DM and IGT was significantly greater in this study than in the rural population $(\mathrm{P}<0.001$ in both instances). The prevalence of DM was significantly, more than that of IGT $(\mathrm{P}<0.001)$ within both the rural and urban populations [19].

The latest estimates of the prevalence of diabetes in the year 2010 by Shah et al., [21] were accepted by United Nations and published by International Diabetic Federation (IDF). Estimating more than 50 million people having diabetes in India in 2010, and figure to increase to more than 87 million with an annual increase of 1813 thousand people if the preventive measures were not taken to combat this menace (Table 2).

\subsection{Epidemiology Diabetic Foot Ulcer (DFU) in People with Diabetes}

Foot problems in diabetic patients account for more hospital admissions than any other long-term complications of diabetes and also result in increasing morbidity and mortality. The diabetic foot syndrome encompasses a number of pathologies, including diabetic neuropathy, peripheral vascular disease, Charcot neuroarthropathy, foot ulceration, osteomyelitis, and the potentially preventable end point amputation. Patients with the diabetic foot can also have multiple diabetic complications and caring for such patients may require attention to many different areas.

The reported rate of foot ulcer prevalence was as high as $11.6 \%$ by Centres for Disease Control and Prevention (CDCP) (2003) in United States. The $10.6 \%$ prevalence rate of DFU was reported in USA in a population based study, with $2.2 \%$ an annual rate on incidence [22]. In the same year, $7.4 \%$ prevalence rate of DFU was reported by Walter et al., [23] in United Kingdom. The average risk of foot ulcer development in peoples with diabetes is estimated to be $15 \%$ [24]. The annual incidence of population based studies has been summarized in table 3 .

Table 3. Summary of selected population based studies estimating incidence and prevalence of diabetic foot ulcers.

\begin{tabular}{|c|c|c|c|c|}
\hline Study (country) & Country & Population based & Annual Incidence (\%) & Prevalence $(\%)$ \\
\hline Abott et al., [146] & $\begin{array}{l}\text { United } \\
\text { Kingdom }\end{array}$ & Registered $\mathrm{T} 1 \& \mathrm{~T} 2$ in 6 UK districts $\mathrm{N}=15,692$ & - & $\begin{array}{l}5.5 \% \text { white european, } 1.8 \% \text { South } \\
\text { Asian, } 2.7 \% \text { African Caribbean }\end{array}$ \\
\hline CDCP [147] & USA & US BRFSS & - & $11.8 \%$ \\
\hline Kumal et al., [44] & UK & 3 UK cities $N=811$ & - & $5.3 \%$ \\
\hline Moss et al., [22] & USA & Population based study $\mathrm{N}=1834$ & $2.2 \%$ & $10.6 \%$ \\
\hline Muller et al., [148] & Netherland & Registered T2DM (1992-1998) N=3827 & $2.2 \%$ & - \\
\hline Ramsey et al., [149] & USA & $\begin{array}{l}\text { Registered T1DM \& T2DM (1992-1995) } \\
\mathrm{N}=8905\end{array}$ & $1.9 \%$ & - \\
\hline Walter et al., [23] & UK & Registered patient from 10 hospitals $\mathrm{N}=1077$ & - & $7.4 \%$ \\
\hline Gadepalli et al., [88] & India & T1DM \& T2DM, Hospital based N=80 & - & - \\
\hline Zubair et al., [89] & India & T1DM \& T2DM, Hospital Based N=162 & - & - \\
\hline
\end{tabular}

Table 3. Summary of selected population based studies estimating incidence and prevalence of diabetic foot ulcers. (Continue)

\begin{tabular}{llll}
\hline Study (country) & Country & Ulcer definition & Method of ulcer asscessment \\
\hline Abott et al., [146] & United Kingdom & Wagner grade $\geq 1$ foot lesion & Clinical examination+chart review \\
CDCP [147] & USA & Foot sore that did not heal for $>4$ weeks & Random digital telephonic \\
Kumal et al., [44] & UK & Wagner grade $\geq 1$ foot lesion & Direct examination by expert \\
Moss et al., [22] & USA & NA & Medical history questionaire and 4 year later \\
Muller et al., [148] & Netherland & Full thickness skin loss on the foot & Abstracted medical record \\
Ramsey et al., [149] & USA & Ulcer of lower leg & Medical record \\
Walter et al., [23] & UK & Wagner grade & Direct examination \\
Gadepalli et al., [88] & India & Wagner grade & Direct examination by expert \\
Zubair et al., [89] & India & Wagner Grade, University of Taxes & Direct examination \\
\hline
\end{tabular}

\section{Classification of Foot Lesions in Diabetes Mellitus}

For evaluation and determination of the severity of diabetic foot, various classification systems are in use now, that attempt to encompass different characteristics of an ulcer (namely site, depth, the presence of neuropathy, infection, and ischemia, etc) [25-31] including Wagner System, University of Texas System and a hybrid System, Depth Ischemic classification, the PEDIS System. It seems that poor clinical outcomes are generally associated with infection, peripheral vascular disease, and increasing wound depth; it also appears that the progressive cumulative effect of these comorbidities contribute to a greater likelihood of a diabetic foot ulcer leading to a lower-limb amputation.

The three main diabetic foot classification system are discussed that are commonly used in clinical diagnosis of 
diabetic foot.

These were:

3.1. Wagner-Meggitt Classification

3.2. Depth-Ischemic classification

3.3. University of Texas classification

\subsection{Meggit-Wagner Classification}

Most common and widely used Classification system is the Wagner Diabetic Foot classification System (Table 15). This system is basically anatomical with gradations of superficial ulcer, deep ulcer, abscess osteitis, gangrene of the fore foot, and gangrene of the entire foot. Only grade 3 addresses the problem of infection. In this system foot lesions are divided into different grades starting from grade 0 to grade 5 . Grade 0 includes high risk foot but no active lesion and grade 5 includes gangrene of entire foot. But this system does not mention about ischemia or neuropathy and that is the drawback of this system.

\subsection{Depth-Ischemic Classification}

This classification is a modification of Wagner-Meggit system. The purpose of this classification system is to make the classification more accurate, rational, easier to distinguish between wound and vascularity of foot, to elucidate the difference among the grades 2 and 3, and to improve the correlation of treatment to the grade. Details of depth Ischemic classification are presented in table 16.

\subsection{University of Texas Classification System}

Another popular system is the University of Texas San Antonio System which incorporates lesion depth and ischemia (Table 17). It is actually a modification of Wagner System .In this system each grade of Wagner System is further divided into stages according to the presence of infection or ischemia or combination of both. This system is somewhat superior in predicting the outcome in comparison to the Wagner System.

\section{Location of Foot Ulcer in Diabetes, its Outcome and Time to Outcome}

The site of ulcer, etiology and treatment methodology varies according to the population of different region. Dorsal or plantar site are the most common site of ulcer in diabetic patients followed by plantar metatarsal heads and the heel [32, 33]. Ulcer severity is more important than site in determining the final outcome [32]. [34] The details of site of ulcer and its treatment were shown in table 4 . Several reported that several factors were contributing to the outcome of DFU, which is irrespective of similar type of care treatment [35-38]. Oyibo et al., [34] found that the ulcer surface area were strongly significant in ulcers that healed, did not heal and proceeded to amputation. The larger size of ulcer will take longer duration of healing time. After pooling all the five studies, Margolis and colleagues reported that the neuropathic ulcer took longer duration to heel, 20 weeks for ulcer $<2 \mathrm{~cm} 2$ [35]. Sex, age and
HbA1c level had no impact on the healing of ulcer in a multivariate analysis model. In medical record of 72,525 diabetic foot wounds from 81,106 patients from 38 US states, it was conformed that the ulcer/wound that were older, larger in size and higher in foot grade $(\geq 3)$ were more likely to have higher duration of healing time after the age and sex were adjusted [34]. Patients in all these studies were receiving the similar ulcer care, including off-loading, wound debridement and healing treatment [35-37, 39].

Table 4. Wagner-Meggitt Classification System.

\begin{tabular}{ll}
\hline Grade & Lesion \\
\hline 0 & No open Lesion \\
1 & Superficial ulcer \\
2 & Deep ulcer to tendon or joint capsule \\
3 & Deep ulcer with abscess, osteomyelitis, or joint sepsis \\
4 & Local gangrene- fore foot or heel \\
5 & Gangrene of entire foot \\
\hline
\end{tabular}

\section{Risk Factors for Diabetic Foot Ulcer}

The independent risk factors for foot ulcer are demographic variables, risk factors for foot, health findings and history, health care and education.

\subsection{Demographic Variables}

The national wide Behavioural Risk Factors Surveillance System (BRFSS), demographic variables from 2000-2002 for diabetic peoples with or without foot ulcer in a population based non-institutionalized adults over age of 18 years, self-reported foot ulcer prevalence of $13.7 \%$ in a age group $18-44$ years, followed by $45-64$ years $(13.4 \%)$, 65-74 years $(9.6 \%)$ and those with over 75 years $(9 \%)$. Similar prevalence of foot ulcer were reported in males and females $(11.8 \%$ and $11.9 \%$ respectively) and this increased to $9 \%$ in patients with duration of diabetes $<6$ years and $19 \%$ in those with duration of diabetes $>21$ years (CDCP, 2003). Using the same data, the relative Odds ratio of foot ulcer was compared with ethnic group, as reference. Compared to Asians, the Relative Odds ratio were 1.5, with African Americans (OR 2.8), Hispanic (OR 4.2), Native Americans (OR 7.4) and in Whites (OR 1.8) [38]. Abbott and Colleagues reported the prevalence rates, Europeans (5.5\%), South Asians (1.9\%), and African (2.7\%). Asian men \& women had similarly low foot ulcer rates, few of the patients were on the insulin; and significantly fewer Asian had ever smoked [40].

\subsection{Foot Risk Factors}

Various risk factors for foot ulcer include peripheral neuropathy, peripheral arterial disease, and foot deformity. Several quantitative and semi-quantitative methodology are used for peripheral neuropathy and peripheral arterial studies and these are summarised in table 05 . Both baseline vibration perception threshold (VPT) and combined score of reflexes and muscle strength are significant predictors of ulcer [40]. Later, a 2.03 relative risk of development of ulceration were 
found in patients who were to be detected by 5.07 (10-g) Semmes-Weinstein Monofilament, which is a semi-quantitative assessment method [41, 42] reported that the elevated levels of VPT greater than 24 volts as significant risk factors for foot ulcer. While Moss et al., 1992 did not show any significant association between peripheral neuropathy and foot ulcer. The presence of two or loss of the four pedal pulses, either with or without the presence of oedema, indicate the presence of PVD [43]. A significant correlation between absence of pedal pulse or history of peripheral arterial revascularization with foot ulcer have been reported by Kumar et al., [44] and Walter et al., [23]. Only a single study reported that foot deformity as a significant risk factor [43] for diabetic foot ulcer.

Table 5. depth Ischemic classification System.

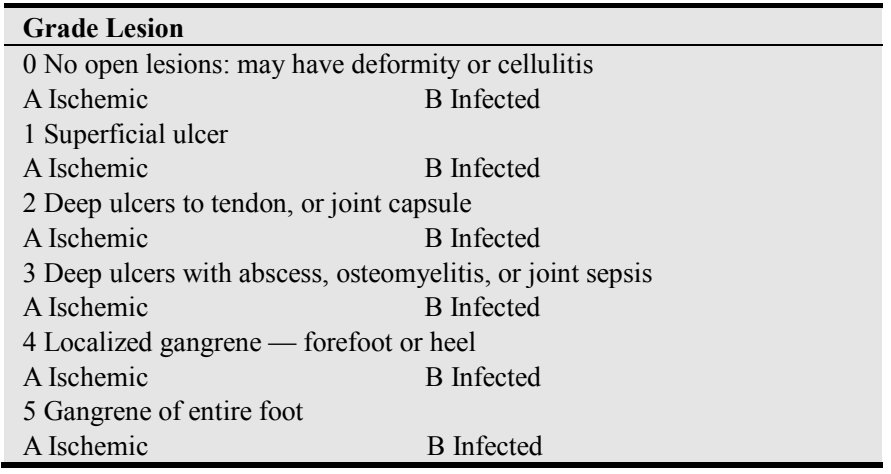

\subsection{Health Findings and History}

Clinical history includes longer duration of diabetes, high HbA1c, prior history of foot ulcer amputation and smoking habit, a significant relation were reported in between these and development of ulcer [22, 23, 44, 45]. The elevated levels of HbA1c were significantly associated with development of foot ulcer with an Odds ratio of 1.6 for every $2 \%$ increase in A1c level [22]. Smoking is one of the significant factor associated with the DFU in a cohort study [22] while it was non-significant as reported by many [42-44, 46]. A significant risk of association was also observed with prior history of foot ulcer [43] with an OR 2.57. Kumar et al., [44] also showed similar pattern with an OR 12.7 for subsequent amputations.

\subsection{Health Care and Education.}

Health care and education were also reported to be an important risk factor for foot ulcer. In a cohort study showed an elevated risk of 2.19 for prior attendance at podiatric clinic [43]. This variable is most likely an intermediary in pathway of foot ulcer development.

\section{Epidemiology of Lower Limb Amputation}

\subsection{Incidence, Prevalence \& Amputation}

The amputation rate varies across the geographical locations within the country and or within the countries. The Global Lower Extremity Amputation Study Group first time reported the rate of amputation in lower limb in diabetic subjects, pooling a data from the 10 study centres over a period of 2 years in USA. They reported a lowest rate 2.8 per 100,000 persons per year in Madrid, Spain and the highest in Navojo population with a rate of amputation as 43.9 per 100,000 per year [47]. The annual incidence of amputation has been shown in table 06. The annual incidences of amputation were changes from 0.7 per 1000 in East Asia to 31.0 per 1000 in USA [46, 48]. Lower Extremity Amputation (LEA) rates can be 15 to 40 times higher among the diabetic versus non diabetic populations [49]. It was also suggested that, amputation was done for disease management and remained a global problem for all persons with diabetes [50]. The same risk factors that predispose to ulceration can also generally be considered contributing causes of amputation, albeit with several modifications.

Another frequently described risk factor for amputation is chronic hyperglycemia. Results of the Diabetes Control and Complications Trial (DCCT) and the United Kingdom Prospective Diabetes Study [2] support the long held theory that chronic poor control of diabetes is associated with a host of systemic complications [1,2]. The best predictor for amputation is a history of previous amputation. A past history of a lower extremity ulceration or amputation increases the risk for further ulceration, infection, and subsequent amputation $[41,51]$. It may also be inferred that patients with previous ulceration possess all the risk factors for developing ulceration, having demonstrated that they already have the component elements in the causal pathway [52]. Reamputation can be attributed to disease progression, non-healing wounds, and additional risk factors for limb loss that develop as a result of the first amputation. One study reported a 5 year mortality rate of $68 \%$ after lower limb amputation, with lower survival rates in those patients with higher levels of amputation. Persons with renal failure or more proximal levels of amputation have a poor prognosis and higher mortality rate. Those who undergo a diabetes- related amputation have a $40 \%$ to $50 \%$ chance of undergoing a contralateral amputation within 2 years [53].

Table 6. University of Texas Classification System.

\begin{tabular}{lllll}
\hline \multirow{2}{*}{ Stages } & Grades & & & \\
\cline { 2 - 5 } & $\mathbf{0}$ & I & II & III \\
\hline A & Pre-or post ulcerative lesions & Superficial wound not involving & Wound penetrating to tendon or & Wound penetrating to bone \\
& Completely epithelialized & tendon capsule or bone & capsule & or joint \\
B & With infection & With infection & With infection & With infection \\
C & With ischemia & With ischemia & With ischemia & With ischemia \\
D & With infection and ischemia & With infection and ischemia & With infection and ischemia & With infection and ischemia \\
\hline
\end{tabular}




\subsection{Risk Factors for Non-Traumatic Lower Limb Amputation in Peoples with Diabetes}

Population based study of diabetic individuals with non-traumatic amputations from the US hospitals were the three main well known geographical risk factors: age, gender and non-white racial status. In the year 2003, there was an increase in amputation rate by 2 fold in those who were at the age of $\geq 75$ years (CDCP). The importance of quality of care, easily assessable care clinic and socio-economic of patients were also important significant factors in deciding the rate of amputations [49].

The peripheral neuropathy is also associated with the amputation risk. These includes insensitivity to $10 \mathrm{~g}$ monofilament, decrease motor nerve conduction velocity of the deep peroneal nerve and sensory nerve conduction velocity of the sural nerve, VPT, absent or diminished bilateral vibration sensation, and absent Achilles tendon and patellar reflexes. Table 07 shows the studies that reported a statistically significant association between one or more measures of peripheral neuropathy and amputation $[48,51$, 55-60]. While some did not show any association with the amputation and peripheral neuropathy [46, 48, 61, 62].

The peripheral arterial function, as measured by absent or diminished dorsal pedis and posterior tibialis pulses as well as median arterial calcification and its relationship to amputations, is an independent risk factors to predict the amputation in diabetic patients with foot ulcer [48, 51, 54, 55, $57,59,60,62]$. High blood pressure is also an independent predictive risk factor for amputation in various studies $[46,56$, 61]. Six studies have reported no significant role of high blood pressure with amputation rate in their final outcome [48, 54, $55,57,59,60]$. High BP was the significant factor in males and elevated diastolic BP in females for amputation [61].

Long duration of diabetes is also significantly associated with amputation [46, 48, 51, 54-62]. Poor glycemic control as measured by elevated $\mathrm{HbA} 1 \mathrm{c}$ with or without plasma glucose reported to be an important risk factors for increased risk of amputation in a nine analytical studies represented in table 7. Smoking was an independent risk factor for increased risk of amputation in diabetic patients [46] and also the patients with history of prior foot ulcer, an independent risk factor [46, 51, 59]. The retinopathy and its association are also represented in table 7 . There is a statistical significant association between the risk of amputation and presence of retinopathy [46, 48, $54-57,59,61]$.

Table 7. Anatomical Locations of Diabetic Foot Ulcer in three prospective studies.

\begin{tabular}{llll}
\hline & All Ulcers ${ }^{\mathbf{a}}(\mathbf{N}=\mathbf{3 1 4})$ & ${\text { Most severe } \text { Ulcer }^{\mathbf{b}} \text { (N=302) }}$ & All Ulcers followed 6-18 months $\mathbf{~}^{\mathbf{~}}(\mathbf{N}=\mathbf{1 9 4})$ \\
\hline Ulcer Site & & & - \\
Toe(dorsal \& planter) & 51 & 52 & - \\
Planter metatarsals heads, midfoot \& heel & 28 & 37 & - \\
Dorsum of foot & 17 & 11 & - \\
Multiple ulcers & 7 & NA & 78 \\
Forefoot & - & - & 12 \\
Mid-foot & - & - & 10 \\
Hind-foot & - & - & 100 \\
Total & 100 & 100 & \\
& & & \\
Ulcer Outcome & - & - & 16 \\
Unhealed & 63 & 81 & 65 \\
Reepithelialization/primary healing & 24 & 14 & 15 \\
Amputation at any level & 13 & 5 & 3.5 \\
Death & 100 & 100 & 100 \\
Total & & & \\
\hline
\end{tabular}

a: Apelqvist et al [32], b: Reiber et al.[33], c: Oyibo et al [34].

\section{Neuropathic Problems of the Lower Limb in Diabetic Mellitus}

\subsection{Definition, Pain Overview \& Stages of Diabetic Neuropathy}

Definition: The American Diabetes Association has proposed the recommendation on classification, diagnosis, and treatment guidelines of diabetic neuropathy. They reiterated the definition as "the presence of symptoms and/or sign of peripheral nerve dysfunction in people with diabetes after the exclusion of other causes" [63]. Clinical neuropathy is confirmed by the presence of abnormal neurological examination done by physicians who were skilled in these techniques.

Pain Overview: All the symptoms for which physicians are consulted, pain in one form or another, and is the most common and extremely urgent". It is very important to understand that diabetic neuropathy can occur with no pain or with insensate foot or may present with pain in the form of dysesthesias and paraestheisias. $15 \%$ of patients of diabetic patients with neuropathy have been reported to be suffering from pain [64]. Patients may have non-neuropathic pain or 
nociceptive pain or both. Nociceptive pain arises from a stimulus outside the nervous system and is proportionate to receptor stimulation. In acute nociceptive pain, it serves as protective function. The neuropathic pain arises from primary lesion or dysfunction in the nervous system and is disproportionate to receptor stimulation [65]. Neuropathic pain does not require nociceptive stimulation, and there is often other evidence of nerve damage.

Stages: The Mayo clinic staging methods is useful one to describe the different stages of diabetic neuropathy [66]. The different stages are shown in table 8.

Table 8. Risk factors for foot ulcers in patients with diabetes mellitus from final analysis models.

\begin{tabular}{|c|c|c|c|c|}
\hline & & Foot Findings & & \\
\hline Author, type of analysis & Study design, type of diabetes & $\begin{array}{l}\text { Neuropathy (monofilament, reflex, vibration, } \\
\text { or neurological summary) }\end{array}$ & $\begin{array}{ll}\text { Low AAI or } \\
\text { Absent Pulse }\end{array}$ & Deformity \\
\hline $\begin{array}{l}\text { Abbott et al.[150]. } \\
\text { Cox regression analysis }\end{array}$ & $\begin{array}{l}\text { RCT, } \\
\text { patients with VPT } \geq 25 \\
\text { (US, UK, Canada) } \\
\text { T1DM: } 255 \text {, } \\
\text { T2DM: } 780\end{array}$ & $\begin{array}{l}0 \text { Monofilament } \\
+ \text { VPT } \\
+ \text { Reflex }\end{array}$ & Exclusive criteria & \\
\hline $\begin{array}{l}\text { Abbott et al [43]. } \\
\text { Cox regression analysis }\end{array}$ & $\begin{array}{l}\text { Cohort, UK registered patients } \\
\text { of } 6 \text { districts, } \mathrm{T} 1+\mathrm{T} 2=6613\end{array}$ & $\begin{array}{l}\text { 0VPT } \\
\text { +Monofilament } \\
\text { +NDS } \\
\text { +Reflex }\end{array}$ & + & + \\
\hline $\begin{array}{l}\text { Boyko et al [51]. } \\
\text { Cox proportion hazards }\end{array}$ & Cohort, 1285 veterans & 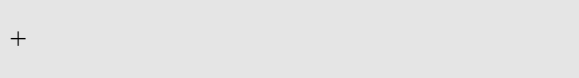 & Data not included & 0 \\
\hline $\begin{array}{l}\text { Carrington et al [152]. } \\
\text { Cox regression analysis }\end{array}$ & $\begin{array}{l}\text { Cohort, single UK clinic, } \\
\text { T1DM: } 83 \\
\text { T2DM: } 86 \\
\text { No DM: } 22\end{array}$ & $\begin{array}{l}\text { +Motor neuropathy } \\
0 \text { VPT } \\
0 \text { Pressure } \\
0 \text { Thermal }\end{array}$ & Exclusive criteria & \\
\hline Kastenbauer et al [42]. & $\begin{array}{l}\text { Cohort, } \\
\text { T2DM: } 187\end{array}$ & $\begin{array}{l}0 \text { Monofilament } \\
+ \text { VPT }\end{array}$ & Exclusive criteria & 0 \\
\hline $\begin{array}{l}\text { Kumar et al [44]. } \\
\text { Logistic regression }\end{array}$ & $\begin{array}{l}\text { Cross sectional } \\
\text { T2DM: } 811 \text { from UK }\end{array}$ & $+\mathrm{NDS}$ & + & \\
\hline $\begin{array}{l}\text { Litzelman et al [153]. } \\
\text { GEE }\end{array}$ & $\begin{array}{l}\text { RCT, } \\
\text { T2DM:352 }\end{array}$ & + Monofilament & & 0 \\
\hline $\begin{array}{l}\text { Moss et al [22]. } \\
\text { Logistic regression }\end{array}$ & $\begin{array}{l}\text { Cohort, } \\
2990 \text { DM }\end{array}$ & & & + \\
\hline $\begin{array}{l}\text { Rith-Najrian et al [45]. } \\
\text { Chi sq test }\end{array}$ & $\begin{array}{l}\text { Cohort. } \\
\text { T2DM:358 Indians }\end{array}$ & +Monofilament & & 0 \\
\hline $\begin{array}{l}\text { Walters et al [23]. } \\
\text { Logistic regression }\end{array}$ & $\begin{array}{l}\text { Cohort. } \\
\text { UK } \\
\text { T1+T2:1077 }\end{array}$ & $\begin{array}{l}\text { + Absent light touch. } \\
+ \text { Impaired pain, perception. } \\
0 \text { VPO }\end{array}$ & $\begin{array}{l}+ \text { Absent pulse. } \\
0 \text { Doppler }\end{array}$ & \\
\hline $\begin{array}{l}\text { Zubair et al [89] } \\
\text { Multivariate }\end{array}$ & $\begin{array}{l}\text { Prospective Cohart } \\
\text { India } \\
\mathrm{T} 1+\mathrm{T} 2=162\end{array}$ & $\begin{array}{l}\text { +Monofilament } \\
\text { +VPT }\end{array}$ & & + \\
\hline
\end{tabular}

Table 8. Risk factors for foot ulcers in patients with diabetes mellitus from final analysis models. (Continue)

\begin{tabular}{|c|c|c|c|c|c|c|}
\hline \multicolumn{7}{|c|}{ Health and health findings } \\
\hline Author, type of analysis & Study design, type of diabetes & Long Duration & High HbA1c & Smoking & Ulcer & LEA \\
\hline $\begin{array}{l}\text { Abbott et al.[150]. } \\
\text { Cox regression analysis }\end{array}$ & $\begin{array}{l}\text { RCT, } \\
\text { patients with VPT } \geq 25 \\
\text { (US, UK, Canada) } \\
\text { T1DM: } 255 \text {, } \\
\text { T2DM: } 780\end{array}$ & 0 & & Exclusion criteria & $\begin{array}{l}\text { Exclusion } \\
\text { criteria }\end{array}$ & \\
\hline $\begin{array}{l}\text { Abbott et al [43]. } \\
\text { Cox regression analysis }\end{array}$ & $\begin{array}{l}\text { Cohort, UK registered patients } \\
\text { of } 6 \text { districts, } \mathrm{T} 1+\mathrm{T} 2=6613\end{array}$ & 0 & & 0 & + & \\
\hline $\begin{array}{l}\text { Boyko et al [51]. } \\
\text { Cox proportion hazards }\end{array}$ & Cohort, 1285 veterans & 0 & + & 0 & + & + \\
\hline $\begin{array}{l}\text { Carrington et al [152]. } \\
\text { Cox regression analysis }\end{array}$ & $\begin{array}{l}\text { Cohort, single UK clinic, } \\
\text { T1DM: } 83 \\
\text { T2DM: } 86 \\
\text { No DM:22 }\end{array}$ & 0 & 0 & & 0 & $\begin{array}{l}\text { Exclusive } \\
\text { criteria }\end{array}$ \\
\hline Kastenbauer et al [42]. & $\begin{array}{l}\text { Cohort, } \\
\text { T2DM: } 187\end{array}$ & 0 & 0 & 0 & $\begin{array}{l}\text { Exclusive } \\
\text { criteria }\end{array}$ & $\begin{array}{l}\text { Exclusive } \\
\text { criteria }\end{array}$ \\
\hline $\begin{array}{l}\text { Kumar et al [44]. } \\
\text { Logistic regression }\end{array}$ & $\begin{array}{l}\text { Cross sectional } \\
\text { T2DM: } 811 \text { from UK }\end{array}$ & + & & 0 & 0 & + \\
\hline $\begin{array}{l}\text { Litzelman et al [153]. } \\
\text { GEE }\end{array}$ & $\begin{array}{l}\text { RCT, } \\
\text { T2DM:352 }\end{array}$ & 0 & 0 & & + & $\begin{array}{l}\text { Exclusive } \\
\text { criteria }\end{array}$ \\
\hline Moss et al [22]. & Cohort, & + & Young & & & \\
\hline
\end{tabular}




\begin{tabular}{|c|c|c|c|c|c|c|}
\hline \multicolumn{7}{|c|}{ Health and health findings } \\
\hline Author, type of analysis & Study design, type of diabetes & Long Duration & High HbA1c & Smoking & Ulcer & LEA \\
\hline Logistic regression & $2990 \mathrm{DM}$ & & & & & \\
\hline $\begin{array}{l}\text { Rith-Najrian et al [45]. } \\
\text { Chi sq test }\end{array}$ & $\begin{array}{l}\text { Cohort. } \\
\text { T2DM:358 Indians }\end{array}$ & + & & & & \\
\hline $\begin{array}{l}\text { Walters et al [23]. } \\
\text { Logistic regression }\end{array}$ & $\begin{array}{l}\text { Cohort. } \\
\text { UK } \\
\text { T1+T2:1077 }\end{array}$ & + & & 0 & & \\
\hline $\begin{array}{l}\text { Zubair et al [89] } \\
\text { Multivariate }\end{array}$ & $\begin{array}{l}\text { Prospective Cohart } \\
\text { India } \\
\mathrm{T} 1+\mathrm{T} 2=162\end{array}$ & 0 & + & + & & + \\
\hline
\end{tabular}

AAI: ankle are index, DM diabetes mellitus, LEA: lower limb amputation, NDS: neuropathic disability score, RCT: randomozed controlled trials, VPT: vibration perception threshold. Blank cell: not studiesd, +: statictically significant, 0 : non-significant.

\subsection{Classification of Diabetic Neuropathy}

Diabetic neuropathy can be classified in several ways as: clinical presentation (symmetrical, focal, or multifocal or painful, paralytic, and ataxic), predominant type of fibers affected (motor, sensory, autonomic), or painful or nonpainful. the classification of diabetic neuropathy was presented in table 09 [67].
Various types of neuropathy have been described in terms of their onset, symmetry, and clinical course (Table 10). A symmetrical distal neuropathy is the most common type with symptoms of numbness, tingling, and burning in the lower feet and lower shins or it can be asymptomatic detected by neurological examination or electrophysiological testing.

Table 9. Age adjusted population based amputation incidence rates among patients with diabetes from selected studies.

\begin{tabular}{|c|c|c|}
\hline Author & Population studies & Annual incidence $/ \mathbf{1 0 0 0}$ \\
\hline \multirow{7}{*}{ Chaturvedi et al [154] } & T1DM: American Indians, & 31.0 \\
\hline & Cuban, & 8.2 \\
\hline & European, & 3.5 \\
\hline & East Asian. & 1.0 \\
\hline & T2DM: American Indians, & 9.7 \\
\hline & Cuban, & 2.0 \\
\hline & European, & 2.5 \\
\hline Humphrey et al [155] & Nauru & 7.6 \\
\hline Humphrey et al [156] & Rochester, USA & 3.8 \\
\hline Letho et al [157] & East \& West Finland & 8.0 \\
\hline \multirow[t]{2}{*}{ Morris et al [158] } & Tayside Scotland & 2.5 \\
\hline & Wisconsin, USA & \\
\hline \multirow[t]{2}{*}{ Moss et al [46] } & Young onset diabetic & 5.1 \\
\hline & Older onset diabetes & 7.1 \\
\hline \multirow{2}{*}{ Siitonen et al [159] } & Incident LEA, & 3.4 Men \\
\hline & Finland & 2.4 Female \\
\hline Trautne et al [160] & Germany & 2.1 \\
\hline \multirow{2}{*}{ Van Houtum and Lavery, [161] } & California, USA & 4.9 \\
\hline & Netherland & 3.6 \\
\hline
\end{tabular}

Table 10. Risk factors for Non-traumatic Lower limb amputations in patients with Diabetes Mellitus from Final analysis models of selected studies.

\begin{tabular}{|c|c|c|c|c|c|c|}
\hline \multirow[b]{2}{*}{ Author, } & \multirow[b]{2}{*}{ Analysis type } & \multirow[b]{2}{*}{ Study design } & \multirow[b]{2}{*}{ Type of diabetes } & \multicolumn{3}{|l|}{ Foot findings } \\
\hline & & & & $\begin{array}{l}\text { Neuropathy } \\
\text { (monofilameny, } \\
\text { vibration, reflex, NCV) }\end{array}$ & $\begin{array}{l}\text { PAD AAI, MAC, } \\
\text { TcPO }_{2} \text {, Pulses }\end{array}$ & HBP \\
\hline Adler et al., [51] & $\begin{array}{l}\text { Multivariate } \\
\text { proportional hazard }\end{array}$ & Cohort & 776; T2DM & + & + & \\
\hline $\begin{array}{l}\text { Hamalainen et al., } \\
\text { [57] }\end{array}$ & Logistic regression & Nested & Case control: 100 & + & + & 0 \\
\hline Hennis et al. [162] & Logistic regression & Case control & $309 \mathrm{DM}$ & + & + & 0 \\
\hline Lee et al., [61] & Cox regression & cohort & $\begin{array}{l}875 \text { T2, Oklahama } \\
\text { Indians }\end{array}$ & & & $\begin{array}{l}+\mathrm{SPB}^{\lambda} \\
+\mathrm{DBP}+\end{array}$ \\
\hline Lehto et al., [48] & Cox regression & Cohort & 1044 T2, Finland & + & + & 0 \\
\hline Mayfield et al., [59] & Logistic regression & $\begin{array}{l}\text { Retrospective case } \\
\text { control }\end{array}$ & $\begin{array}{l}246 \text { T2 Pima } \\
\text { Indians }\end{array}$ & + & + & 0 \\
\hline Moss et al., [46] & Logistic regression & Cohort & $\begin{array}{l}2990 \text { early \& late } \\
\text { onset }\end{array}$ & & & $+\mathrm{DBP}$ \\
\hline
\end{tabular}




\begin{tabular}{|c|c|c|c|c|c|c|}
\hline \multirow[b]{2}{*}{ Author, } & \multirow[b]{2}{*}{ Analysis type } & \multirow[b]{2}{*}{ Study design } & \multirow[b]{2}{*}{ Type of diabetes } & \multicolumn{3}{|l|}{ Foot findings } \\
\hline & & & & $\begin{array}{l}\text { Neuropathy } \\
\text { (monofilameny, } \\
\text { vibration, reflex, NCV) }\end{array}$ & $\begin{array}{l}\text { PAD AAI, MAC, } \\
\text { TcPO }_{2,} \text { Pulses }\end{array}$ & HBP \\
\hline Nelson et al., [54] & Stratified & Cohort & 4399 pima Indians & + & + & 0 \\
\hline Reiber et al., [55] & Logistic regression & $\begin{array}{l}\text { Prospective case } \\
\text { control }\end{array}$ & $316 \mathrm{~T} 1 \mathrm{DM}$ & + & + & 0 \\
\hline Resnick et al., [62] & Logistic regression & Cohort & & & $+\mathrm{ABI}>4.1$ & $\begin{array}{l}\mathrm{OK}=+ \\
\mathrm{Pima}=0\end{array}$ \\
\hline $\begin{array}{l}\text { Selby and Zhang } \\
{[156]}\end{array}$ & Logistic regression & $\begin{array}{l}\text { Nested retrospective } \\
\text { case control }\end{array}$ & $428 \mathrm{~T} 1+\mathrm{T} 2$ & + & & $+\mathrm{SPB}$ \\
\hline Zubair et al [89] & Multivariate & Prospective Cohort & $162(\mathrm{~T} 1+\mathrm{T} 2)$ & + & $\mathrm{ABI}$ & + \\
\hline
\end{tabular}

Table 10. Risk factors for Non-traumatic Lower limb amputations in patients with Diabetes Mellitus from Final analysis models of selected studies. (Continue)

\begin{tabular}{|c|c|c|c|c|c|}
\hline \multirow{2}{*}{ Author, } & \multicolumn{5}{|c|}{ Health and health histoty } \\
\hline & Duration & High HbA1c, FPG & Smoking & Ulcer & Retinopathy \\
\hline Adler et al., [51] & 0 & 0 & 0 & + & \\
\hline Hamalainen et al., [57] & + & 0 & & & \\
\hline Hennis et al. [162] & 0 & + & 0 & 0 & \\
\hline Lee et al., [61] & + & $+\hat{o}$ & 0 & 0 & + \\
\hline Lehto et al., [48] & + & + & 0 & & \\
\hline Mayfield et al., [59] & + & + & 0 & + & + \\
\hline Moss et al., [46] & + & + & + Younger & + & + \\
\hline Nelson et al., [54] & + & + & 0 & & + \\
\hline Reiber et al., [55] & Control variable & + & 0 & & + \\
\hline Resnick et al., [62] & + & + & 0 & & \\
\hline Selby and Zhang [156] & + & + & 0 & & + \\
\hline Zubair et al [89] & + & + & + Young & & + \\
\hline
\end{tabular}

AAI:ankle arm index, DBP:diastolic blood pressure, FPG: fasting plasma glucose, HbA1c: haemoglobin A1c, HBP: high blood pressure, MAC: medial arterial calcification, NCV; nerve conduction velocity, PtEd:patient outpatient education, PVD; peripheral vascular disease, SBP: systolic blood pressure, TcPo: transcutaneous oxygen tension, Blank cell:not studies, +: significant finding, 0: non-significant findings.

\subsection{Risk Factors for Diabetic Neuropathy}

There are two man risk factors for the diabetic neuropathy, non-modefiable and modifiable. The detail overviews are presented in table 11. In a modifiable factor, only the hyperglycemia has been proven to be a significant risk factor via prospective, randomized, multicentric, parallel design clinical study [68]. Whereas other factors listed in the table are significant by retrospective or cross sectional data study only. The non-modifiable factors include older age, longer duration of diabetes, HLA DR3/4 genotype and patients height. Many studies confirm that, male sex are at greater risk but on reanalysing the data, it shows that, it's because of the greater height of male than female and hypothesized that longer nerve are more prone to nerve damage [69].

Table 11. Different stages of Diabetic Neuropathy.

\begin{tabular}{llll}
\hline Stage & Description & Sign/Symptoms & $\begin{array}{l}\text { Abnormal } \\
\text { quantitative test }\end{array}$ \\
\hline 0 & $\begin{array}{l}\text { No Neuropathy } \\
\text { Subclinical } \\
1\end{array}$ & No & No \\
2 & $\begin{array}{l}\text { Neuropathy } \\
\text { Clinical evident }\end{array}$ & Yes & Yes \\
3 & $\begin{array}{l}\text { Neuropathy } \\
\text { Debilitating }\end{array}$ & Yes & Yes \\
\hline
\end{tabular}

\subsection{Pathogenesis of Diabetic Neuropathy}

In the most diabetic complaints, insulin deficiency, and hyperglycemia are the major factors involved in both type of diabetes (type 1 and type 2). In this regard, a multiple retrospective study which support this hypothesis was DCCT trial [1] and UKPDS [67, 70] that are presented in table 12., which is the strongest evidence supporting this mechanism in both type of diabetes.

The pathogenesis of diabetic neuropathy includes various factors, like hyperglycemia $[1,69,70]$, pre-diabetes neuropathy [71, 72], Vaso Nervorum [73], Protein Kinase C pathway activation $[74,75]$, abnormal fatty acid metabolism [76], Polyol pathway [77], Myo-inositol [78], advanced glycated end product [79], antibody to neural tissue [80]. In the year 2004, four major pathogenic pathways mechanism explaining the hyperglycaemic nerve damage [81]. These four major mechanisms are increased intracellular formation of AGEs, increased polyol pathway, activation of protein kinase $\mathrm{C}$ and increased hemosamine pathway flux.

One theory is that due to chronic hyperglycemia in diabetes there is accelerated non-enzymatic glycation of intracellular proteins resulting in the formation of Advanced Glycation End (AGE) products by the so called Maillard reaction [82]. In normal individuals, glucose reacts with amino groups to form some amount of Early Glycosylation products (stable Amadori products) through a nonenzymatic and irreversible process. It has also arisen from intracellular auto-oxidation of glucose to glyoxal, decomposition of the Amadori product to 3-deoxygluconase, and fragmentation of glyceraldehyde-3-phosphate to methylglyoxal. These reactive intracellular dicarbonyls react with amino groups of intracellular and extracellular proteins to form AGEs. 
Different mechanisms have been explained by which AGE precursors have deleterious effects on target tissues. AGE act as recognition signals for uptake and degradation of proteins by macrophages resulting in the production of cytokines, and growth factors like TNF-a, IL-1, IGF-1, GM-CSF, G-CSF, and PDGF and ultimately oxidative stress. Modification of important matrix proteins like type 1 collagen, type 4 collagen, and laminin also occurs, resulting in change in structure and function of extracellular matrix most importantly reduction in endothelial cell adhesion. AGE modified proteins can also alter cellular function through binding to specific AGE receptors (RAGE) on endothelial cells. RAGE belongs to a class of immunoglobulin super family is expressed on the surface of a variety of cell types, including endothelial cells, smooth muscle cells, lymphocytes, monocytes, and neurons. Activation of RAGE triggers the generation of reactive oxygen species and further activation of signalling molecules such as nuclear factor kB, p21, and PKC (Figure 1).

Normally intracellular glucose is predominantly phosphorylated to Glucose 6 phosphate by the enzyme Hexokinase to be metabolized later on by glycolysis and HMP shunt and only some amount is converted to sorbitol by the Polyol pathway. Enzyme Aldose reductase is the rate limiting step in this alternate pathway and it has a low affinity for glucose. Under conditions of hyperglycemia there is increased flux of glucose through this pathway that is about $30 \%$ and is metabolized in this way. In a hyperglycemic environment, however, increased intracellular glucose results in increased enzymatic conversion to the polyalcohol sorbitol, with concomitant decreases in NADPH. The mechanism by which glucose flux through the polyol pathway is detrimental and not clearly defined. It has been proposed that oxidation of sorbitol by NAD + increases the cytosolic ratio of NADH/NAD + , there by inhibiting activity of enzyme glyceraldehydes-3-phosphate dehydrogenase and increasing concentratons of triose phosphate. Elevated triosephosphate concentratons could increase formation of both methylglyoxal, a precursor of AGE and diacylglycerol, thus activating PKC [81]. It has also been found that reduction of glucose to sorbitol by NADPH consumes the cofactor NADPH which is required for regenerating reduced glutathione (GSH). This can lead to oxidative stress as glutathione is an important cellular antioxidant. Some other proposed mechanisms are sorbitol induced osmotic stress and decreased $\mathrm{Na}+, \mathrm{K}+$-ATPase activity. But the sorbitol concentration in diabetic vessels and nerves are too low to be considered significant 83] (Figure 2).

The third important mechanism is the activation of family of Protein Kinase $\mathrm{C}$ enzymes which are cell signaling enzymes. These enzymes are involved in diverse cellular functions ranging from cell growth and differentiation, apoptosis, protein trafficking, cytoskeletal rearrangement, and cell polarity. PKC isofoms are activated by second messenger Diacyl glycerol. In states of hyperglycemia, there is increased concentration of DAG as a result of its denovo synthesis from glyceraldehyde-3-phosphate. Activation of PKC has been associated with suppression of nitric oxide (NO) production via inhibition of insulin stimulated expression of endothelial nitric oxide synthase (eNOS) and stimulation of endothelin 1(ET-10) vasoconstrictor activity. It also leads to increased microvascular matrix protein accumulation by inducing the expression of TGF- $\beta 1$, fibronectin, and type IV collagen. It has also been implicated in the over expression of the fibrinolytic inhibitor PAI-1 and in the activation of pleiotropic transcription factor NF-kB. It also induces expression of the permeability-enhancing factor VEGF (Figure 3).

A fourth hypothesis is that, in states of hyperglycemia there is increase flux of glucose through Hexosamine pathway. Fructose-6-phosphate which is derived from glucose is ultimately converted to UDP-N-acetylglucosamine (UDP-GlcNAc). This product glycosylates the threonine and serine residues of target proteins by the enzyme UDP-GlcNAc, which can alter the functional properties of many transcriptional regulatory factors (Figure 4).

All these were seemed to reflect single hyperglycaemic induced process of overproduction of superoxide by michondrial electron transport chain [80]. These associations might help in to explain the detail mechanism involved in the metabolic syndrome to develope diabetic neuropathy before they are diagnosed as overt type 2 diabetes (Figure 5).

Table 12. Classification of diabetic neuropathy.

\begin{tabular}{ll}
\hline - & Symmetrical distal neuropathy \\
\hline - & Symmetrical Proximal neuropathy \\
& Asymmetrical proximal neuropathy \\
- $\quad$ Cranial & Trunk radiculopathy or mononeuropathy \\
- $\quad$ Limb plexus or mononeuropathy \\
- $\quad$ Multiple mononeuropathy \\
- $\quad$ Entrapment mononeuropathy \\
- Asymmetrical neuropathy and symmetrical distal neuropathy \\
\hline
\end{tabular}

\subsection{Documentation of Neuropathy.}

The documentation of neuropathy involves the following three major steps

7.1. Clinical presentation

7.2. Neurological examination

7.3. Electrophysiological testing

7.1. (i). In the clinical presentation, the major documentation includes type of pain, motor sign \& symptoms, and autonomic neuropathy symptoms.

Types of pain: there are three type of pain as described by David Ross [84]. (a) Dysesthesis has been attributed to cutaneous and subcutaneous and it may be attributed to increased firings of damage or abnormal nociceptive fibers. (b) Paraesthesis pain occurs from several factors like spontaneous activity near the cell body of damage afferent axone in dorsal root ganglion, loss of segment myelinated fibers, ectopic impulse generation from demyelinated patches of myelinated axon and last by increased firings. (c) Muscular pain is believed to be secondary caused by injury to motor neuron (e.g. demyelinated patch). The details of type of pain are shown in table 13. (ii). Motor sign and symptoms: This 
symptom relates with the loss of pro-prioception in toes and ankle, a sign that is commonly used in testing of joint position senses in feet. Leg weakness is typically a late feature of diabetic neuropathy where as ankle weakness is typically the first motor symptoms of diabetic neuropathy. (iii) In Autonomic Neuropathy, the patients usually complain dry and cracked skin, orthostatic dizziness \& urinary retention, etc.

7.2. In the neurological Examination, following are the testing for diabetic neuropathy. Monofilament Testing: on the plantar surface of the great toe and the pulp of the index figure bilaterally to assess the sense of touch in booth feet. The currently available instrument is Semmes Weinstein Monofilament usually made from fine nylon fibre and is designed to give an appropriate pressure to the site. Each monofilament is calibrated to deliver different bowing force which is represented in the form of number that represents the log decimal 10 times the force in milligram ranging from $1.65(0.45 \mathrm{gm})$ to $6.65(447 \mathrm{gm})$ of linear force. The patients inability to sense the force of monofilament 5.07 (10 gm) was considered as neuropathic positive. The second documentation is Deep Tenson Reflex which is an essential part of examination because the deep tendon reflex are reduced or absent in length dependent pattern such as ankle lost first than knee [85]. The third documentation is motor function, which is most common as many patients will have no demonstrable weakness in feet. Once the neuropathy advances to knee, patients begin to complaints about the hand also.

7.3. Electrophysiological Testing. It plays an important role in evaluating both types of neuropathies in patients (suspected and well documented). It defines that which fibre is affected (motor, sensory and autonomic), renders a gross estimate of the duration of neuropathy and even gives insight of the progression also. The electromyography can be used to examine the de-nervation and to decipher chronicity, and later by analysing the morphology of motor nerve.

Table 13. Types of Diabetic Neuropathy.

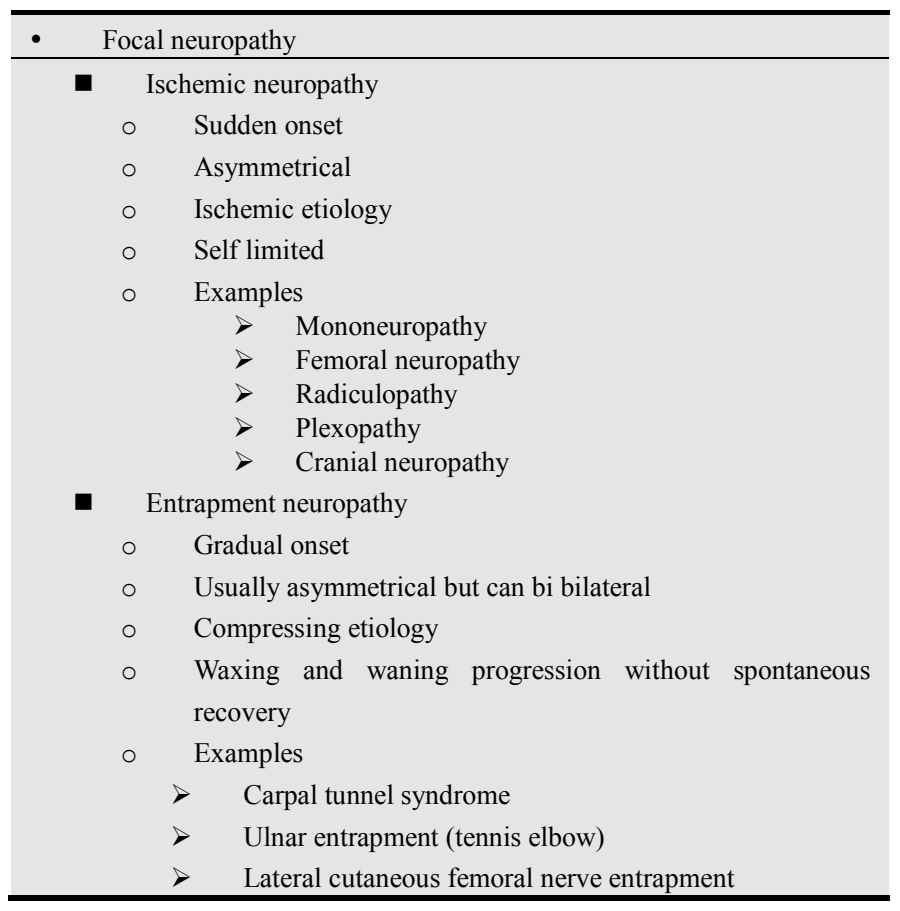

\begin{tabular}{|c|c|}
\hline \multirow[t]{8}{*}{ Di } & $\begin{array}{l}\text { Tarsal tunnel syndrome } \\
\text { e neuropathy }\end{array}$ \\
\hline & Insidious onset \\
\hline & Symmetrical \\
\hline & $\begin{array}{l}\text { Abnormal secondary to vascular metabolic syndrome, } \\
\text { structural and autoimmune aberration. }\end{array}$ \\
\hline & Progression without spontaneous recovery \\
\hline & xample. \\
\hline & Distal symmetrical poly-neuropathy \\
\hline & Autonomic neuropathy \\
\hline
\end{tabular}

\section{Peripheral Vascular Disease in Diabetes}

The studies of various risk factors which provide the insight into the pathogenesis of peripheral vascular atherosclerosis in diabetes have been already discussed in PAD. A strong correlation among them in relation to PVD has been well established in various geographical locations Seattle, Washington [86], Kuopio, Finland [87] In Finland, Kuopio increased VLDL, LDL-C levels [87]. Data from the Indian subcontinent regarding PVD, among patients are very scarce. The prevalence of neuropathy was $75 \%$ in a study in North India [88] in 2006 and in 2012, neuropathy was 50.6\% [89] . In The Chennai Urban Population Study (CUPS), the overall prevalence rate of PVD in enrolled subjects was $3.2 \%, 2.7 \%$ in patients with normal glucose tolerance group, and in impaired glucose tolerance group it was $2.9 \%$ [90]. In the type 2 diabetic patients, the prevalence of PVD in newly diagnosed diabetic was $3.5 \%$ and $7.8 \%$ in known diabetic subjects. Whereas, the overall PVD prevalence was $6.3 \%$ which was higher from overall subjects enrolled in CUPS study. The prevalence of PVD in India is comparable to that report from Sri Lanka [91] but is considerably lower than that reported from Rochester study [92] and the Hoorn Study [93]. This suggests that different susceptibility factors may operate in different populations. Alternatively, it could also be because the prevalence of certain well-known risk factors, e.g., smoking, could be less common in certain populations. Finally, it could simply be a reflection of the younger age structure of the population, as shown by a steep increase in prevalence rates of PVD in those patients $>70$ years of age. The differences between the prevalence rates of CAD and PVD in CUPS study are quite striking. Thus, whereas CAD occurs with increased prevalence and at a younger age (premature CAD), PVD appears to show the opposite trend, i.e., lower prevalence and occurrence in older age-groups. This finding suggests that the pathogenic mechanisms for CAD and PVD could be different. In addition, CUPS results suggest that screening for CAD using the ABI [94] is unlikely to be useful in a South Asian population. Indeed, the risk factors for PVD itself appear to differ in different populations. A study from China [95] reported that hypertension, diabetes, elevated serum cholesterol, LDL cholesterol, triglycerides, fibrinogen, and hyperglycemia are associated with PVD. A U.S. study showed diabetes to be the major risk factor for PVD [96]. In 
Greece, serum triglycerides alone were found to be associated with PVD in diabetic subjects [97]. Other reports showed microalbuminuria [98], homocysteine [99], and lipoprotein $(\alpha)$ [100] to be associated with PVD. However, the commonly known risk factors do not explain the high prevalence of PVD seen in some ethnic groups [87, 101]. Although smoking provided a 2.7 times higher risk for PVD, this did not reach statistical significance. The absence of association with smoking can be attributed to a small sample size or to the underreporting of smoking because of cultural and other barriers. Unfortunately, we could not perform serum nicotine estimation to quantify smoking in this study.

\subsection{Pathophysiology of PVD}

Atherosclerosis (also known as arteriosclerotic vascular disease or ASVD) is a condition in which an artery wall thickens as a result of the accumulation of fatty materials such as cholesterol. It is a syndrome affecting arterial blood vessels, a chronic inflammatory response in the walls of arteries, caused largely by the accumulation of macrophage white blood cells promoted by low-density lipoproteins (plasma proteins that carry cholesterol and triglycerides) without adequate removal of fats and cholesterol from the macrophages by functional high density lipoproteins (HDL), (apoA-1 Milano). Some researchers believe that atherosclerosis may be caused by an infection of the vascular smooth muscle cells; chickens, for example, develop atherosclerosis when infected with the Marek's disease herpesvirus [94].

Atherogenesis is the developmental process of atheromatous plaques. It is characterized by a remodeling of arteries leading to subendothelial accumulation of fatty substances called plaques. The build-up of an atheromatous plaque is a slow process, develope over a period of several years through a complex series of cellular events occurring within the arterial wall, and in response to a variety of local vascular circulating factors. One recent theory suggests that, for unknown reasons, leukocytes, such as monocytes or basophils, begin to attack the endothelium of the artery lumen in cardiac muscle (Figure 06). The ensuing inflammation leads to formation of atheromatous plaques in the arterial tunica intima, a region of the vessel wall located between the endothelium and the tunica media. The bulk of these lesions is made of excess fat, collagen, and elastin. At first, as the plaques grow, only wall thickening occurs without any narrowing. Stenosis is a late event, which may never occur and is often the result of repeated plaque rupture and healing responses, not just the atherosclerotic process by itself.

The initial damage to the blood vessel wall results in an inflammatory response. Monocytes (a type of white blood cell) enter the artery wall from the bloodstream, with platelets adhering to the area of insult. This may be promoted by redox signaling induction of factors such as VCAM-1, which recruit circulating monocytes. The monocytes differentiate into macrophages, which ingest oxidized LDL, slowly turning into large "foam cells" - so-described because of their changed appearance resulting from the numerous internal cytoplasmic vesicles and resulting high lipid content. Under the microscope, the lesion now appears as a fatty streak. Foam cells eventually die, and further propagate the inflammatory process. There is also smooth muscle proliferation and migration from tunica media to intima responding to cytokines secreted by damaged endothelial cells. This would cause the formation of a fibrous capsule covering the fatty streak (Figure 7).

\section{Biomechanics of the Foot in Diabetes}

Most of the skin injuries on the feet of diabetic patients with neuropathy mainly occur in forefoot, with equal distribution on plantar and dorsal surface [102], and those on plantar are frequently occur at site of higher pressure areas [103, 104]. Now various tools are available to measure the pressure areas under bare foot walking and also inside the shoes. The overall component of brief examination of foot in two minutes was shown in table 14.

One of the important aspects of biomechanics study is the planter pressure examination. Defined by Armstrong et al., [7] a pressure of $750 \mathrm{kPa}$ will provide a cut-off value to differentiate between the low risk and high risk patients. The second most important aspect is foot deformity and the various risk factors for foot deformity are depicted in table 14, which is the key factor for injury in the foot. The high foot pressure on dorsal and plantar surface will cause most skin injury. This may lead to vulnerable areas on the foot predisposing to ulceration. Motor neuropathy, with imbalance of the flexor and extensor muscles in the foot, frequently results in foot deformity, with prominent metatarsal heads and clawing of the toes, In turn, the combination of proprioceptive loss due to neuropathy and the prominence of metatarsal heads lead to increases in the pressures and load under diabetic foot [83]. In the charcot process, the foot is also erythematous, hot, and swollen, but in the healed stage, these findings are absent. The third aspect is the callus in the foot. The etiology of callus is still unknown. In a study by Murray et al [105], the callus was present with the loss of sensation in foot, that have high risk of developing an ulcer. It is therefore, strongly recommended to remove the callus from the foot using appropriate measures. The third important aspect is the limited joint mobility.

The relationship of joint limitation and plantar ulceration was established in a study by Delbridge et. al., [106]. There was a significant correlation between joint mobility at the sub-talar joint and mobility at the first metatarsophalangeal joint. Birke et al., [107] demonstrated the relationship of hallux limitus with great toe ulceration. They found significantly decreased great toe extension using a torque range-of-motion system in diabetic patients with a history of great toe ulcers compared to diabetic patients with a history of ulcers at other sites and normal controls. Fernando et al., [108] found significantly increased foot pressures using pedobarography in diabetic patients with limited subtalar and metatarsophalangeal joints compared to diabetic patients and controls without limited mobility. As shown by these studies, 
sensory loss and joint hypomobility may result in increased pressure and plantar ulceration. Orthoses and footwear, designed to spread the stresses over time or reduce the function motion requirements (e.g., rocker sole) during walking time, are needed to compensate for hypomobility in the feet of patients with hypomobility [109].

Table 14. Risk Factors for Diabetic Neuropathy.

\begin{tabular}{cl}
\hline - & Non-modifiable risk factor \\
\hline$\circ$ & Old age \\
0 & Longer duration of diabetes \\
0 & HLA DR3/4 genotype \\
$\circ$ & Greater Height \\
Modifiable risk factor \\
0 & Hyperglycemia \\
0 & Hypertension \\
$\circ$ & Elevated Cholesterol Level \\
0 & Smoking \\
0 & Heavy alcohol use \\
\hline
\end{tabular}

Table 15. DCCT \& UKPDS Landmark Clinical trials of Glucose control.

\begin{tabular}{lll}
\hline Variables & DCCT & UKPDS \\
\hline Type of diabetes patients & Type 1 & Type 2 \\
Number of patients & 1441 & 4209 \\
Study length (yrs) & 10 & 20 \\
Length of patient followup (yrs) & 5 & 10 \\
Average HbA1c (\%) & & \\
Standard therapy & 8.9 & 7.9 \\
Intensive therapy & 7.1 & 7.0 \\
Average glucose level (mg/dl) & & \\
Standard therapy & 231 & 117 \\
Intensive therapy & 155 & 147 \\
Reduction in retinopathy (\%) & 76 & 21 \\
Reduction in Nephropathy (\%) & 56 & 34 \\
Reduction in Neuropathy (\%) & 60 & 25 \\
\hline
\end{tabular}

Table 16. Descriptors of Type of Pain in Neuropathy.

- Dysestheis

Burning sensation, sunburn type, skin tingles, painful sensation when something touches.

- $\quad$ Paraesthesis

Pins and needles like, electric shock like, Numb but achy, feel like ice water shock, shooting pain, lancinating pain

- Muscular Pain

Dull ache, night cramp, band like sensation, drawing sensation, deep ache, spasms.

Table 17. A "Two minute foot examination" to check for biomechanical and other risk factors once a patient has been at risk of neuropathy or vascular disease.

\begin{tabular}{ll}
\hline $\begin{array}{l}\text { Evaluation } \\
\text { Component }\end{array}$ & Look for \\
\hline Surface Exam & $\begin{array}{l}\text { Ulcer, callus, hemorrhage in callus, blister, maceration } \\
\text { between toe, mbreaks in skin, skin infection, edema, } \\
\text { erythema, temperature. }\end{array}$ \\
Nail Exam & $\begin{array}{l}\text { Fungal infection, ingrown toenail, injury. } \\
\text { Prominent metatarsal head, clawed toes or } \\
\text { hammertoes, rocker bottom foot deformity, prior } \\
\text { amputations. } \\
\text { Examination of } \\
\text { shoes }\end{array}$ \\
\hline
\end{tabular}

\section{Infection Problems of the Foot in Diabetic Patients}

The infection in the foot of diabetic patient is a major medical, social and economic problem and the leading cause of hospitalization for patients with DFU. The trio of problem leading to diabetic foot is neuropathy, vascular changes and infection. Infections of various types may be more common and are more often severe in patients with diabetes mellitus $[110,111]$. On the basis of result of large retrospective cohort study, nearly half of all the diabetic patients have atleast one hospitalization in their lifespan for treatment of infection in Canada [112]. The risk was 1.21 times in diabetic subjects when compared with control group. Foot infections are the most common in diabetic patients range from relatively mild to limb threatening (or life threatening). Almost all the infections begin as a minor problem may progress to involve deep tissue, joints, or bony especially if it was not managed. The infection complicates the pathological picture of diabetic foot $[113,114]$. The worst and the most feared outcome of infection in DFU is lower limb amputation [52]. Diabetes continues to be the leading cause of lower limb amputations worldwide. The WHO has estimated that there are approximately 250,000 lower limb amputations per year in diabetic patients in Europe alone [115].

\subsection{Epidemiology of Infection in Diabetic Foot Patients}

Soft tissue and foot infections are significantly associated with diabetes. The relative frequency of cellulites is 9 times more in diabetic patients than in non-diabetic subjects. Similarly, patients with osteomyelitis were more who had infections in foot in their report and the relative proportions of hospitalization of patients with osteomyelitis were 12 times more than in non-diabetic subjects [110]. The risk of hospitalization was more than non-diabetic subjects. Significant risk factors that were independent risk factors in a multivariate analysis were infections to bone and duration of ulcer $>30$ days and peripheral vascular disease [116]. The variable in 112 diabetic foot ulcer were history of previous amputation, peripheral vascular disease and neuropathy but not socioeconomic status as the significant risk factors [117]. Fortunately, upto $50 \%$ diabetic individual who had one foot infection episode will have another episode within few years. Thus infection is often the proximate cause leading to amputation in their outcome [37, 55]. India, with a population of more than 1.1 billion, has the dubious distinction of having a larger number of people with diabetes and there were no major difference in the risk factors when compared with developed countries, while the clinical features may vary in developing countries because of the regional factors [118].

Role of Pathogens in diabetic foot infection in India. In a study, the prevalence of pathogens in diabetic foot infections in relation to parameters such as Wagner's grading, duration of diabetes, and healing times was studied [119]. It was found that in 654 diabetic patients, 728 pathogens were isolated. Aerobic pathogens were isolated in $66.8 \%$ patients and 
anaerobic pathogens were isolated in $33.2 \%$.

Neuropathy was once again found to be a common factor in diabetic patients infected with both aerobic and anaerobic pathogens. Ulcers infected with anaerobic pathogens showed a longer healing time than ulcers infected with aerobic pathogens $(\mathrm{P}<0.001)$. Among the frequently discovered aerobic pathogens, the Enterobacteriaceae family was the most prominent at $48 \%$, the Staphylococcus species was quite prominent at $18.2 \%$, Streptococcus stands at $16.8 \%$ and Pseudomonas at $17 \%$. Among anaerobes Peptostreptococcus and Clostridium formed 69.4\%, Gram-negative anaerobes such as Bactericides and Fusobacterium were present in $30.6 \%$. Healing times were longer when strict aerobic pathogen Pseudomonas and strict anaerobic pathogens were present $(136.1 \pm 28.6$ and $136.4 \pm 34.7$ days, respectively). In another study 162 diabetic foot ulcer patients with clinical sigh and symptoms of infection were studied. Males were predominant $(74.9 \%)$, all patients were from Wagner grade $3-5$, majority of the subjects were from type 2 diabetes. The mean duration of diabetes $>10$ years was $31.4 \%$. The neuropathy was present in 50.6\%, retinopathy and hypertension in $50.6 \%$ \& 56.7\% respectively. Among 162 patients, 51 has ESBL infection and $81.8 \%$ had CTX-M gene positivity, $50.0 \%$ TEM and $46.9 \%$ SHV in ESBL positive isolates. In their study, PVD, neuropathy, ulcer size $(>4 \mathrm{~cm} 2)$, poor glycemic control, higher grade of ulcer were associated with ESBL infection [89]. The epidemiological data on diabetic foot worldwide were presented in table 18 .

Table 18. Recommended evaluation of diabetic patients with foot ulcer.

\begin{tabular}{ll}
\hline - & $\begin{array}{l}\text { Describe the lesion (cellulites, ulcer, etc) and any drainage (serous, } \\
\text { purulent). }\end{array}$ \\
\hline - & Enumerate the presence or absence and degree of various signs of \\
inflammation. \\
- & Define the status of infection and determine the probable cause. \\
- & foreign particle. \\
- & Probe any skin break with sterile probe to see whether bone is \\
- & Palpate and record pedel pulse, use Doppler instrument if necessary \\
- & Evaluate neurological status \\
- & Cleaned and debride the wound \\
- & Culture the cleaned wound \\
& Order the plain radiograph
\end{tabular}

\subsection{Pathogenesis and Impact of Microbes on DFU}

A variety of physiology and metabolic distributions conspire to place diabetes patients at high risk for foot wounds. Microbial colonization of wound is inevitable, usually with endogenous bacteria, but these are potentially pathogenic in wound [121]. Immunological disturbance are also an important predisposing factors of pathophysiology of foot ulcer; these includes abnormalities of migration, phagocytosis, intracellular killing, and chemotaxis. The cellular immune response and monocyte function are also reduced in diabetes.
Poor granulation formation, prolonged abscess presence and impaired wound healing are further complicating the diabetic foot ulcer. Once the skin has been breached, continued mobilization on a broken area impairs the healing process. Inevitably, direct contiguous spread of microbes on the skin follows on, with colonization and infection of superficial and then deeper tissues is likely if the process is allowed to proceed unchecked. Both the healing process and the response to infection are further compromised by vascular insufficiency, which is commonly present in patients burdened with complications of diabetes [122]. The infection in diabetic foot is mainly by aerobic bacteria [88, 89, 102, 114, 123-125]. Anaerobic bacterial infection also plays a significant role in the infection of DFU but this has not been studied since the strict anaerobic culture techniques are not available at all the clinical laboratories. The impact of anaerobes was reported first by Louie et al., [126] and subsequently by many researchers $[88,89,123,125,127,128]$. There are only few reports available on the incidence of fungal pathogens in diabetic foot infections [129, 130-132]. DFU infection is usually polymicrobial in nature and this was first reported by Louie et al., [126], and subsequently by many [88, 89, 102, $114,124,125]$. The unique anatomy of the foot is the main reason that infection is potentially serious in this location [133]. The structure compartment, tendons, sheaths, and neurovascular bundles tend to favour the proximal spread of infection. The deep planter spaces were divided into medial, central, and lateral compartments. The infections may spread from one compartment to another at their calcaneal or by direct performation of septae, but lateral or dorsal spread is a late sign on infection [134].

\subsection{Criteria of Infection}

A critical bacterial load, synergic relationship between bacterial species and the presence of specific pathogens have been proposed as predictors of infection. The critical microbial load might directly affect the healing of both acute and chronic wounds as first reported by Bendy et al, (135). The Consensus Development Conference on Diabetic Foot Wound Care (136), agreed that a DFU should be considered infected when there are purulent secretions or there is presence of two or more signs of inflammation (erythema, warmth, tenderness, heat, induration). Chronic wounds by their very nature may not always display the classic symptoms of infection (pain, erythema, oedema, heat and purulence) and it has been suggested that an expanded list, including signs specific to secondary wounds (such as serous exudate plus concurrent inflammation, delayed healing, discolouration of granulation tissue, friable granulation tissue, foul odour and wound breakdown) be employed to identify infection (137).

\section{Antibiotic Therapy}

\subsection{Route of Therapy}

The antibiotic therapy usually be given intravenously for systemic ill patients, with severe infection and those who are 
unable to tolerate oral agents. After a patient significantly responds to the antibiotic treatment in 3-5 days, most of the patients are shifted to oral antibiotics (138). Oral antibiotic therapy is less expensive and more convenient. For mildly infected patients, tropical therapy is the better option of treatment. This treatment has several advantages, including high local drug levels, avoidance of systemin adverse effect (139). The patients with PVD, therapautic antibiotic concentrations with many agents are often not achieved in tissue even while the serum concentrations are adequate (140). In one procedure, called retrograde venous perfusion, antibiotic solution are injected under pressure into a foot vein while sphygmomanometer is inflated on the thigh. Recently calcium sulphate beads were used in the surgical sites and open wound (141).

\subsection{Choice of Antibiotic Therapy and Duration}

Many patients will begin therapy, with pending the results of would culture. The narrow spectrum antibiotics may be used in mild infected ulcers until the report of culture \& sensitivity are received to modify the treatment accordingly, selecting antibiotic agents that empirically active against Staphylococci and other Streptococci also. The wounds with foul smell and necrotic and gangrenous usually be treated with anti-anaerobic antibiotics and later on the treatment will be modified according to the reports. On the other hand if the infection is not significantly responding to treatment, the treatment should be changed to cover all the isolated organisms. The antimicrobial spectrum, are shown in table 19 $(a, b, c, d)$. The necessary duration of antibiotics therapy has not been well studied. For mild to moderate infections, 1-2 week course are found to be effective (142), and for severe, it was 2-4 weeks time. The antibiotic treatment should be discontinued when the clinical sign and symptoms of infection have resolved, even the wound has not completely healed.

Table 4: Selected antibiotics that may be used for diabetic foot infections (Adopted from Clinical Practice Guideline-2007. Médecine et maladies infectieuses 37 (2007) 14-25).

Table 19. Simple Clinical classification of severity of DFU.

\begin{tabular}{lllll}
\hline & Superficial ulcer or cellulitis present & Deep tissue or bone involve & $\begin{array}{l}\text { Tissue necrosis or } \\
\text { gangrene present }\end{array}$ & $\begin{array}{l}\text { Systemic toxicity or metabolic } \\
\text { instability present }\end{array}$ \\
\hline Mild & $\sqrt{ }$ & - & \pm & - \\
Moderate & $\sqrt{ }$ & \pm (no gas or fasciitis $)$ & $\pm($ minimal) & - \\
Severe & $\sqrt{ }$ & \pm & \pm & $\sqrt{ }$ \\
\hline
\end{tabular}

$\sqrt{ }=$ present $\pm=$ may or may not; - = not present

Table 20. Clinical characteristics that help to define the severity of an infection.

\begin{tabular}{lll}
\hline Features & Mild Infection & Serious infection \\
\hline Presentation & Slowely progressive & Acute or rapidly progressive \\
Ulceration & Involves skin only & Penetration to subcutaneous tissue \\
Tissue involved & Epidermal and dermal & Fascia, muscle, tendon, joint, bone. \\
Cellulitis & Minimal $(<2 \mathrm{~cm} \mathrm{ring)}$ & Extensive, or distant from ulceration \\
Local signs & Slight inflammation & Severe inflammation, crepitus, bullae. \\
Systemic signs & None or minimal & Fever, chills, hypotension, confusion, volume depletion, leukocytosis \\
Metabolic control & Mildly abnormal & Severe hyperglycemia, acidosis, azotemia \\
Foot vasculature & Minimal impaired (reduce pulse) & Absent pulse, reduced ankle or toe blood pressure \\
Complicating features & None or minimal (callus, ulcer) & Gangrene, Escher, foreign body, abscess, marked edema, osteomyelitis. \\
\hline
\end{tabular}

Table 21. Selected antibiotics that may be used for diabetic foot infections (Adopted from Clinical Practice Guideline-2007. Médecine et maladies infectieuses 37 (2007) 14-25).

Table 21 (a). for Enterobacteriaceae.

\begin{tabular}{|c|c|c|c|c|}
\hline Enterobacteriaceae & & & & \\
\hline Molecule & Dosage/ 24h & Route of administration & Dose interval & Comment \\
\hline \multirow{5}{*}{$\begin{array}{l}\text { Cefotaxime } \\
\text { ofloxacin or ciprofloxacin }\end{array}$} & $200 \mathrm{mg} / \mathrm{kg}$ per day & IV & $4-6 \mathrm{~h}$ & \multirow{5}{*}{ Oral route as soon as possible } \\
\hline & $600 \mathrm{mg}$ per day & IV/ Oral & $8 \mathrm{~h}$ & \\
\hline & $800-1200 \mathrm{mg}$ per day & IV & $8 \mathrm{~h}$ & \\
\hline & or & or & or & \\
\hline & $1000-1500 \mathrm{mg}$ per day & Oral & $12 \mathrm{~h}$ & \\
\hline \multicolumn{5}{|l|}{ OR } \\
\hline \multirow{4}{*}{ ofloxacin or ciprofloxacin } & $600 \mathrm{mg}$ per day & IV/ Oral & $8 \mathrm{~h}$ & \multirow{4}{*}{ Oral route as soon as possible } \\
\hline & $800-1200 \mathrm{mg}$ per day & IV & $8 \mathrm{~h}$ & \\
\hline & & or & or & \\
\hline & $1000-1500 \mathrm{mg}$ per day & Oral & $12 \mathrm{~h}$ & \\
\hline
\end{tabular}


Table 21 (b). for Streptococcus infection

\begin{tabular}{|c|c|c|c|c|}
\hline \multicolumn{5}{|c|}{ Streptococcus spp } \\
\hline Molecule & Dosage/24h & Route of administration & Dose interval & Comment \\
\hline $\begin{array}{l}\text { Amoxicilin } \\
+ \text { rifampicin }\end{array}$ & $\begin{array}{l}150-200 \mathrm{mg} / \mathrm{kg} \text { per day } \\
20-30 \mathrm{mg} / \mathrm{kg} \text { per day }\end{array}$ & $\begin{array}{l}\text { IV } \\
\text { IV/ Oral }\end{array}$ & $\begin{array}{l}4-6 h \\
8 \text { or } 12 h\end{array}$ & $\begin{array}{l}\text { Change to oral route as soon as possible } \\
\text { IV for first } 24-48 \text { hours, then oral route at the } \\
\text { physician's discretion }\end{array}$ \\
\hline OR & & & & \\
\hline $\begin{array}{l}\text { Clindamycin } \\
\text { + rifampicin } \\
\text { OR }\end{array}$ & $\begin{array}{l}1800 \mathrm{mg} \text { per day } \\
20-30 \mathrm{mg} / \mathrm{kg} \text { per day }\end{array}$ & $\begin{array}{l}\text { IV/ Oral } \\
\text { IV/ Oral }\end{array}$ & $\begin{array}{l}4-6 h \\
8-12 h\end{array}$ & oral route as soon as possible \\
\hline Vancomycin & $\begin{array}{l}1 \mathrm{~g} \text { (loading dose) } \\
\text { then } 30 \mathrm{mg} / \mathrm{kg}\end{array}$ & $\begin{array}{l}\text { IV } \\
\text { IV infusion }\end{array}$ & $\begin{array}{l}\text { Loading dose }(1 \mathrm{~h}) \\
\text { IV infusion or/ } 12 \mathrm{~h}\end{array}$ & Adjust to serum assays $^{\mathrm{a}}$ \\
\hline $\begin{array}{l}\text { + rifampicin } \\
\text { OR }\end{array}$ & $20-30 \mathrm{mg} / \mathrm{kg}$ per day & IV/ Oral & $8-12 h$ & \\
\hline $\begin{array}{l}\text { Teicoplanin } \\
+ \text { rifampicin }\end{array}$ & $\begin{array}{l}24 \mathrm{mg} / \mathrm{kg} \text { per day } \\
\text { then } 12 \mathrm{mg} / \mathrm{kg} \text { per day } \\
20-30 \mathrm{mg} / \mathrm{kg} \text { per day }\end{array}$ & $\begin{array}{l}\text { IV/ subcutaneous } \\
\text { Subcutaneous } \\
\text { IV/ Oral }\end{array}$ & $\begin{array}{l}12 \mathrm{~h} \text { loading dose } \\
24 \mathrm{~h} \\
8 \text { or } 12 \mathrm{~h}\end{array}$ & $\begin{array}{l}\text { For } 48 \mathrm{~h} \text {, then } \\
\text { Every } 24 \mathrm{~h}^{\mathrm{a}}\end{array}$ \\
\hline
\end{tabular}

a Adjust the dosages to obtain tough concentrations (discontinuous IV) or plateau concentrations (continuous IV) of $30 \mathrm{mg} / \mathrm{l}$ for vancomycin, or a tough concentration of $30-40 \mathrm{mg} / \mathrm{l}$ by HPLC for teicoplanin

${ }^{\mathrm{b}}$ Only if susceptible to erythromycin

Table 21 (c). for MRSA \& MSSA.

\begin{tabular}{|c|c|c|c|c|}
\hline \multicolumn{5}{|c|}{ Methicilin - resistant $S$. Aureus } \\
\hline Molecule & Dosage/24h & Route of administration & Dose interval & Comment \\
\hline Vancomycin & $1 \mathrm{~g}$ (loading dose) & IV & Loading dose (1h) & Adjust according to serum assays ${ }^{a}$ \\
\hline & then $30 \mathrm{mg} / \mathrm{kg}$ & IV infusion & IV infusion or/ $12 \mathrm{~h}$ & For $48 \mathrm{~h}$ \\
\hline \pm gentamicin & $4 \mathrm{mg} / \mathrm{kg}$ per day & IV & $24 \mathrm{~h}$ & IV for first $24-48$ hours, then oral route as \\
\hline $\begin{array}{l}\text { OR + rifampicin } \\
\text { OR + fosfomycin }\end{array}$ & $20-30 \mathrm{mg} / \mathrm{kg}$ per day & IV/ Oral & 8 or $12 \mathrm{~h}$ & soon as possible \\
\hline 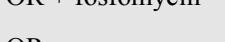 & 200 ing/кg рет Uау & & & Infusion over $1-2 \mathrm{~h}$ \\
\hline \multicolumn{5}{|l|}{ OR } \\
\hline $\begin{array}{l}\text { Rifampicin } \\
+ \text { fusidic acid }\end{array}$ & $\begin{array}{l}20-30 \mathrm{mg} / \mathrm{kg} \text { per day } \\
1500 \mathrm{mg} \text { per day }\end{array}$ & $\begin{array}{l}\text { IV/ Oral } \\
\text { IV/ Oral }\end{array}$ & $\begin{array}{l}8 \text { or } 12 \mathrm{~h} \\
8 \mathrm{~h}\end{array}$ & $\begin{array}{l}\text { IV for first } 24-48 \text { hours, then oral route as } \\
\text { soon as possible }\end{array}$ \\
\hline OR & & & & \\
\hline $\begin{array}{l}\text { [Trimethoprim }+ \\
\text { Sulfamethoxazole] }\end{array}$ & $640 / 3200 \mathrm{mg}$ & IV/ Oral & $\begin{array}{l}\text { (equivalent to } 2 \text { tab/12h } \\
\text { of [Trimethoprim }+\end{array}$ & IV for first $24-48$ hours, then oral route as \\
\hline + rifampicin & $20-30 \mathrm{mg} / \mathrm{kg}$ per day & IV/ Oral & $\begin{array}{l}\text { Sulfamethoxazole] } \\
8 \text { or } 12 \mathrm{~h}\end{array}$ & soon as possible \\
\hline \multicolumn{5}{|l|}{ OR } \\
\hline \multirow[t]{2}{*}{ Teicoplanin } & $24 \mathrm{mg} / \mathrm{kg}$ per day & IV/ Subcutaneous & $12 \mathrm{~h}$ loading dose & \\
\hline & $12 \mathrm{mg} / \mathrm{kg}$ per day & Subcutaneous & $24 \mathrm{~h}$ & for $48 \mathrm{~h}$, then every $24 \mathrm{~h}^{\mathrm{a}}$ \\
\hline + rifampicin & $20-30 \mathrm{mg} / \mathrm{kg}$ per day & IV/ Oral & 8 or $12 \mathrm{~h}$ & \\
\hline
\end{tabular}

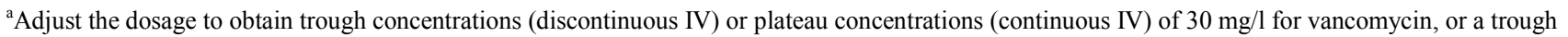
concentration of $30-40 \mathrm{mg} / \mathrm{l}$ by HPLC for teicoplanin

Table 21 (c). for MRSA \& MSSA. (Continue).

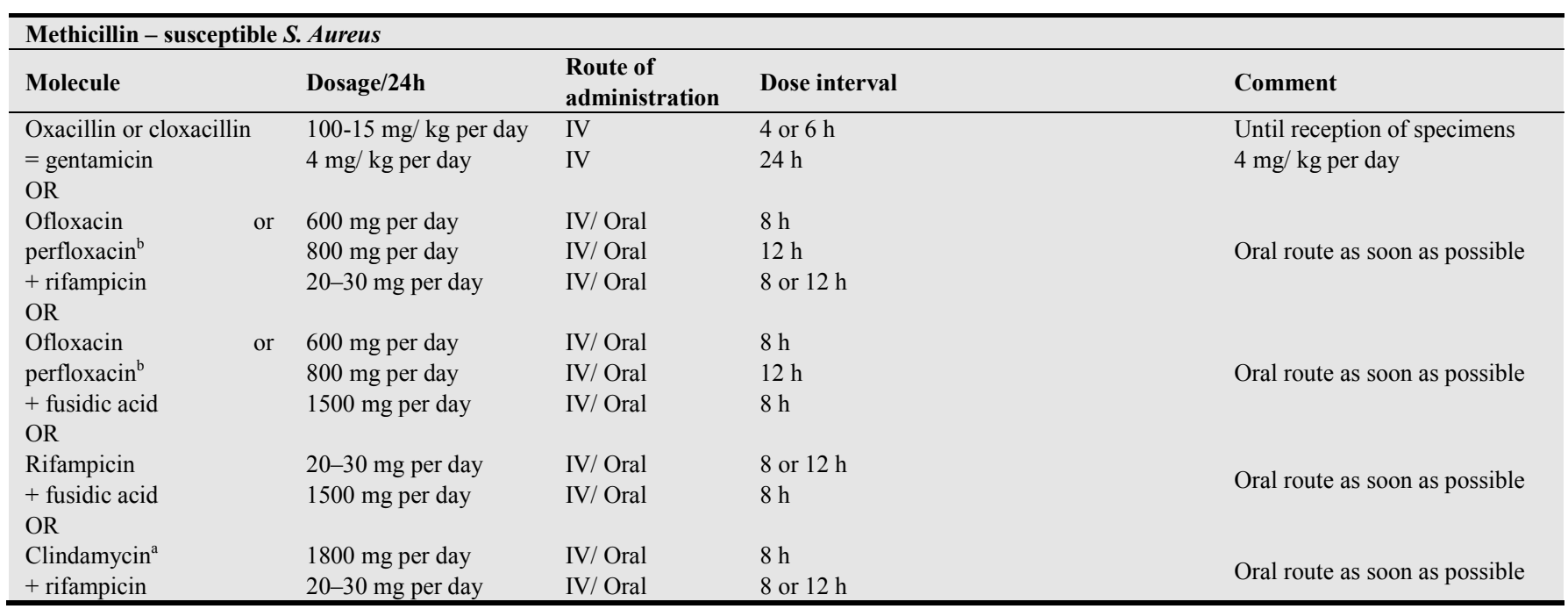




\begin{tabular}{|c|c|c|c|c|c|}
\hline \multicolumn{6}{|c|}{ Methicillin - susceptible $S$. Aureus } \\
\hline Molecule & & Dosage/24h & $\begin{array}{l}\text { Route of } \\
\text { administration }\end{array}$ & Dose interval & Comment \\
\hline \multicolumn{6}{|l|}{$\overline{\mathrm{OR}}$} \\
\hline $\begin{array}{l}\text { [Trimethoprim } \\
\text { sulfamethoxazole] }\end{array}$ & + & $640 / 3200 \mathrm{mg}$ & IV/ Oral & \multirow{2}{*}{$\begin{array}{l}12 \mathrm{~h} \\
\text { (equivalent to } 2 \mathrm{tab} / 12 \mathrm{~h} \text { of [Trimethoprim }+ \\
\text { sulfamethoxazole]) } \\
8-12 \mathrm{~h}\end{array}$} & \multirow{2}{*}{ Oral route as soon as possible } \\
\hline + rifampicin & & 20-30 mg per day & IV/ Oral & & \\
\hline
\end{tabular}

${ }^{\mathrm{a} O}$ Only if susceptible to erythromycin

${ }^{\mathrm{b}}$ Caution in subjects $>60$ years $(1 / 2$ dose $)$

Table 21 (d). First line antibiotics for Diabetic foot ulcer (excluding osteomyelitis).

\begin{tabular}{|c|c|c|}
\hline \multicolumn{3}{|c|}{ First-line antibiotics in diabetes foot infections (excluding osteomyelitis) } \\
\hline Type of infection & Suspected pathogens & Antibiotic therapy \\
\hline $\begin{array}{l}\text { Recent infection of a superficial } \\
\text { wound }\end{array}$ & $\begin{array}{l}\text { MSSA }^{\mathrm{b}} \\
\text { S.pyogenes }\end{array}$ & Cloxacillin or cephalexin or [amoxicillin + clavulanate] or clindamycin \\
\hline$(<1$ month $)$ & $\begin{array}{l}\text { MRSA }^{\mathrm{c}} \\
\text { MSSA }^{\mathrm{b}}\end{array}$ & $\begin{array}{l}\text { Pristinamycin or linezolide or vancomycin or teicoplanin } \\
\text { Oxacillin } \mathrm{AG}^{\mathrm{a}}\end{array}$ \\
\hline Extensive cellulitis & S.pyogenes & \\
\hline & $\begin{array}{l}\text { MRSA }^{\mathrm{c}} \\
\text { MSSA }^{\mathrm{b}}\end{array}$ & $\begin{array}{l}\text { Vancomycin or teicoplanin or linezolide } \\
\text { [Amoxicillin + clavulanate] } \mathrm{AG}^{\mathrm{a}}\end{array}$ \\
\hline $\begin{array}{l}\text { Deep and/ or chronic lesion with } \\
\text { or without sepsis }\end{array}$ & $\begin{array}{l}\text { S. pyogenes, } \mathrm{GNB}^{\mathrm{d}} \text {, anaerobes } \\
\text { MRSA }^{\mathrm{c}} \\
\text { MSSA }^{\mathrm{b}} \\
\text { S. pyogenes, GNB } \\
\text { MRSA }^{\mathrm{d}}, \mathrm{GNB}^{\mathrm{d}} \text {, anaerobes } \\
\text { anaeroes }\end{array}$ & $\begin{array}{l}\text { + vancomycin or teicoplanin or linezolide } \\
{[\text { Piperacillin }+ \text { tazobactam }] \text { or }[\text { ticarcillin }+ \text { clavulanate }]+\mathrm{AG}^{\mathrm{a}}} \\
\text { Imipenem or ertapenem }+[\text { vancomycin or teicoplanin or linezolide }]+\mathrm{AG}^{\mathrm{a}}\end{array}$ \\
\hline
\end{tabular}

Shaded zone: oral outpatient treatment; for the other cases, treatment is initially parenteral, followed by oral therapy when possible, depending on the course and susceptibility profile of the bacteria isolated.

${ }^{a} \mathrm{AG}$ : aminoglycosides (gentamicin or netilmicin)

${ }^{b}$ MSSA: methicillin- susceptible Staphylococcus aureus

${ }^{c}$ MRSA: methicillin- resistant Staphylococcus aureus

${ }^{\mathrm{d}} \mathrm{GNB}$ : Gram-negative bacilli

\subsection{Outcome of Antibiotic Therapy}

The clinical response to mild and moderate infection can be expected to be $80-90 \%$ and this rate of treatment output are further reported to decrease to $50-60 \%$, the infections are of deep or more extensive type, patients usually require surgical intervention in the form of minor or major. Approximately $2 / 3$ of these patients require amputations in their feet or one or more bone resection (143) and long term outcome are reported to be achieved in $80 \%$ of patients (144). In many patients, above ankle amputations are avoided and the uses of aggressive antibiotic therapy with minor and major surgical intervention are required (145).

\section{References}

[1] DCCT Research Group. The effect of intensive treatment of diabetes on the development and progression of long-term complications in insulin-dependent diabetes mellitus. N Engl J Med. 1993; 329:977-986.

[2] United Kingdom Prospective Diabetes Study Group (UKPDS). Intensive blood glucose control with sulfonylureas or insulin compared with conventional treatment and risk of complications in patients with type 2 diabetes (UKPDS). Lancet 1998; 352: 837-853.

[3] King H, Rewers M. Global estimates for prevalence of diabetes mellitus and impaired glucose tolerance in adults. WHO Ad Hoc Diabetes Reporting Group. Diabetes Care 1993;16:
$157-177$.

[4] Amos AF, McCarty DJ, Zimmet P, The rising global burden of diabetes and its complications: estimates and projections to the year 2010, Diabet Med 1997; 14 (5) S1-S85.

[5] King H, Aubert R, Herman W. Global burden of diabetes, 1995-2025: prevalence, numerical estimates and projections, Diabetes Care 1998; 21 (9):1414-1431.

[6] Wild S, Roglic G, Green A, et al. Global prevalence of diabetes: estimates for the year 2000 and projections for 2030, Diabetes Care 2004; 27 (5): 1047-1053.

[7] Armstrong DG, Peters EJG, Athanasiou KA, et al. Is there a critical level of planter foot pressure to identify patients at risk for neuropathic foot ulcerations? J Foot Ankle Surg 1998; 37(4):303-307.

[8] International Diabetes Federation, Diabetes Atlas, 2nd ed., International Diabetes Federation, Brussels, 2003.

[9] International Diabetes Federation, Diabetes Atlas, 3rd ed., International Diabetes Federation, Brussels, 2006.

[10] Whiting DR, Guariguata L, Weil C, Shaw J. IDF diabetes atlas: global estimates of the prevalence of diabetes for 2011 and 2030. Diabetes Res Clin Pract. 2011; 94(3):311-321.

[11] Ramachandran A, Snehalatha C, Latha E, et al. Impacts of urbanization on the lifestyle and on the prevalence of diabetes in native Asian Indian population. Diabetes Res Clin Pract 1999; 44: 207-213. 
[12] Ahuja MMS. Epidemiological studies on diabetes mellitus in India. In: Ahuja MMS, editor. Epidemiology of diabetes in developing countries. New Delhi: Interprint 1979; 29-38.

[13] Ramachandran A, Jali MV, Mohan V, et al. High prevalence of diabetes in an urban population in south India. BMJ 1988; 297 : 587-90.

[14] Sridhar GR, Rao PV, Ahuja MMS. Epidemiology of diabetes and its complications. In: RSSDI textbook of diabetes mellitus. Hyderabad: Research Society for the Study of Diabetes in India 2002: 95-112.

[15] Rao PV, Ushabala P, Seshaiah V, et al. The Eluru survey: prevalence of known diabetes in a rural Indian population. Diabetes Res Clin Pract 1989; 7 :29-31.

[16] Zargar AH, Khan AK, Masoodi SR, et al. Prevalence of type 2 diabetes mellitus and impaired glucose tolerance in the Kashmir Valley of the Indian subcontinent. Diabetes Res Clin Pract 2000; 47: 135-6.

[17] Ramachandran A, Snehalatha C, Kapur A, et al. Diabetes Epidemiology Study Group in India (DESI). High prevalence of diabetes and impaired glucose tolerance in India: National Urban Diabetes Survey. Diabetologia 2001; 44 :1094-101.

[18] Gupta A, Gupta R, Sarna M, et al. Prevalence of diabetes, impaired fasting glucose and insulin resistance syndrome in an urban Indian population. Diabetes Res Clin Pract 2003; 61: 69-76.

[19] Menon VU, Kumar KV, Gilchrist A, et al. Prevalence of known and undetected diabetes and associated risk factors in central Kerala - ADEPS. Diabetes Res Clin Pract 2006; 74: 289-94.

[20] Sadikot SM, Nigam A, Das S, et al. The burden of diabetes and impaired fasting glucose in India using the WHO 1999 critetia. Prevalence of diabetes in India study (PODIS). On behalf of Diabetes India, Diabetes Research and Clinical Practice 2004; 66: 301-307.

[21] Shah JE, Sicree RA, Zimmet P. Global estimation of the prevalence of diabetes for 2010 and 2030. Diab Res Clin Prac 2010; 87(4); 4-14.

[22] Moss SE, Klein R, Klein B. The prevalence and incidence of lower extremity amputation in a diabetic population. Arch. Intern. Med. 1992; 152: 610-616.

[23] Walters DP, Gatling W, Mullee MA, et al. The distribution and severity of diabetic foot disease: A community study with comparison to a non-diabetic group. Diabet Med 1992; 9:354-358.

[24] Palumbo PJ, Melton LJI. Peripheral vascular disease and diabetes. In National Diabetes Data Group(ed): Diabetes In America, 2nd ed (NIH publ. no. 495-1468). Washington, DC, U.S. Government Printing Office. 1995:401-408.

[25] Oakley W, Caterall CF: Aetiology and management of lesions of the feet in diabetes. Br Med J. 1956; 27:953 -955.

[26] Shea JD. Pressure sores: classification and management. Clin Orthop 1975; $112: 89-100$.

[27] Wagner FW: The dysvascular foot: a system of diagnosis and treatment. Foot Ankle 1981; 2:64 -122.

[28] Knighton DR, Ciresi KF, Fiegel VD, et al. Classification and treatment of chronic nonhealing wounds: successful treatment with autologous platelet-derived wound healing factors
(PDWHF). Ann Surg. 1986; 204: 332-330.

[29] Kaufman J, Breeding L, Rosenberg N. Anatomical location of acute diabetic foot infection: its influence on the outcome of treatment. Am Surg. 1987; 53:109 -112.

[30] Jones EW, Peacock I, McLain S, et al. A clinicopathological study of diabetic foot ulcers. Diabet Med. 1987; 4:475 -479.

[31] Lavery LA, Armstrong DG, Harkless LB: Classification of diabetic foot wounds. J Foot Ankle Surg. 1996; 35: 528-531.

[32] Apelqvist J, Castenfors J, Larsson J. Wound classification is more important than site of ulceration in the outcome of diabetic foot ulcers. Diabet Med 1989; 6:526-530.

[33] Reiber GE, Lipsky BA, Gibbons GW. The burden of diabetic foot ulcers. Am. J. Surg. 1998; 176(Suppl. 2A):5S-10S.

[34] Oyibo SO, Jude EB, Tarawneh I, et al. The effect of ulcer size and site, patient's age, sex and type and duration of diabetes on the outcome of diabetic foot ulcers. Diabet Med 2001; 18(2):133-138.

[35] Margolis DJ, Kantor J, Santanna J, et al. Risk factors for delayed healing of neuropathic diabetic foot ulcers: A pooled analysis. Arch Dermatol 2000; 136(12):1531-1535.

[36] Margolis DJ, Allen-Taylor L, Hoffstad O, Berlin JA. Diabetic neuropathic foot ulcers: The association of wound size, wound duration, and wound grade on wound healing. Diabetes Care 2002; 25(10): 835-1839.

[37] Pecoraro RE, Ahroni J, Boyko EJ, et al. Chronology and determinants of tissue repair in diabetic lower extremity ulcers. Diabetes 1991; 40: 1305-1313.

[38] McNeely MJ, Bokyo EJ. Diabetes related comorbitidies in Asian Americans: Results of a National Health Survey. J Diabetes Complications 2005; 19(2):101-106.

[39] Sheehan P, Jones P, Caselli A, et al. Percent change in wound area of diabetic foot ulcers over a 4 -week period is a robust predictor of complete healing in a 12 -week prospective trial. Diabetes Care 2003; 26(6):1879-1882.

[40] Abbott CA, Vileikyte L, Williamson S, et al. Multicentre study of the incidence of and predictive risk factors for diabetic neuropathic foot ulceration. Diabetes Care 2004; 94(5):379-83.

[41] Boyko EJ, Ahroni JH, Stensel V, et al. A prospective study of risk factors for diabetic foot ulcer: the Seattle Diabetic Foot Study. Diabetes Care. 1999; 22:1036-42.

[42] Kastenbauer T, Sauseng S, Sokol G, et al. A prospective study of predictors for foot ulcerations in type 2 diabetes. J American Podiat Med Assoc 2001; 91(7):343-350.

[43] Abbott CA, Carrington AL, Ashe H, et al. The North-West Diabetes Foot Care Study: Incidence of, and risk factors for, new diabetic foot ulceration in a community-based patient cohort. Diabet Med 2002; 19(5):377-384.

[44] Kumar S, Ashe HA, Parnell LN, et al. The prevalence of foot ulceration and its correlates in type 2 diabetic patients: a population-based study. Diabet. Med. 1994; 11: 480-484.

[45] Rith-Najarian SJ, Stolusky T, Gohdes DM. Identifying diabetic patient at high risk for lower extremity amputation in a primary health care setting: A prospective evaluation of simple screening criteria. Diabetes Care 1992; 15(10):1386-1389. 
[46] Moss SE, Klein R, Klein BE. The 14-year incidence of lower extremity amputations in a diabetic population. The Wisconsin Epidemiolog Study of Diabetic Retinopathy. Diabetes Care 1999; 22(6)951-959.

[47] Global Lower Extremity Amputation Study Group(GLEASG): Epidemiology of lower extremity amputation in centres in Europe, North America and East Asia. Br J Surg 2000; 87(3):328-337.

[48] Lehto S, Pyorala K, Ronnemaa T, et al. Risk fators predicting lower extremity amputation in NIDDM. Diabetes Care 1996; 19(6):607-612.

[49] Resnick HE, Valsania P, Phillips CL. Diabetes mellitus and non-traumatic lower extremity amputation in black and white Americans: The national health and nutrition examination survey epidemiological follow-up study, 1971-1992. Arch Intern Med 1999; 159:2470-2475.

[50] Jeffcoate WJ. The incidence of amputation in diabetes. Acta Chir Beig. 2005; 105: 140-144.

[51] Adler AI, Boyko EJ, Ahroni J, Smith DG. Lower extremity amputation in diabetes: the independent effects of peripheral vascular disease, sensory neuropathy, and foot ulcers. Diabetes Care 1999; 22:1029-1035.

[52] Reiber GE, Bokyo EJ, Smith DG. Lower extremity foot ulcers and amputations in diabetes. In National Diabetes Data Group (ed): Diabetes in America, 2nd ed (NIH publ. no.95 1468). Washington, DC, U.S. Government Printing Office: 409-428, 1995.

[53] Tentolouris N, Al-Sabbagh S, Walker MG, et al. Mortality in diabetic and nondiabetic patients after amputations performed from 1990 to 1995: a year follosw up study. Diabetes Care. 2004 ; 27: 1598-1604.

[54] Nelson RG, Gohdes DM, Everhart JE, et al. Lower extremity amputations in NIDDM: 12-yr follow up study in Pima Indians. Diabetes Care. 1988; 11: 8-16.

[55] Reiber GE, Pecoraro RE, Koepsell TD. Risk factors for amputation in patients with diabetes mellitus: a case control study. Ann Intern Med 1992; 117: 97-105.

[56] Selby ZV, Zhang D. Risk factors for lower extremity amputation in persons with diabetes. Diabetes Care 1995; 18(4): 509-516.

[57] Hamalainen H, Ronnemma T, Halonen JP, et al. Factors predicting lower extremity amputations in patients with type 1 or type 2 diabetes mellitus: A population-based 7 year follow-up study. J Int Med 1999; 246:97-103.

[58] Selby JV, Karter AJ, Ackerson LM, et al. Developing a prediction rule from automated clinical database to identify high-risk patients in a large population with diabetes. Diabetes Care 2001; 24(9):1547-1555.

[59] Mayfield JA, Reiber GE, Nelson RG, et al. A foot risk classification system to predict diabetic amputation in Pima Indians. Diabetes Care 1996; 19(7):704-709.

[60] Hennis AJJ, Fraser HS, Jonnalagadda R, et al. Explainations for the high risk of diabetes-related amputation in a Carribean population of black African descent and potential for prevention. Diabetes Care 2004; 27(11):2636-2641.

[61] Lee JS, Lu M, Lee VS, et al. Lower extremity amputation .
Incidence, risk factors, and mortality in the Oklahoma Indian Diabetes Study. Diabetes. 1993; 42: 876-882.

[62] Resnick HE, Carter EA, Sosenko JM, et al. Incidence of lower extremity amputation in American Indians:The Strong Heart Study. Diabetes Care 2004; 27(8):1885-1891.

[63] Boulton AJM, Gries FA, Jervell JA. Guidelines for the diagnostic and outpatient management of diabetic peripheral neuropathy. Diabet Med 15:508-514, 1998.

[64] Dyck PJ, Kratz KM, Karnes JL, et al. The prevalence by staged severity of various types of diabetic neuropathy, retinopathy and nephropathy in a population based cohort: The Rochester Diabetic Neuropathy Study. Neurology.1993; 43:817-824.

[65] Serra J. Overview of neuropathic pain syndromes. Acta Neurol Scand 1999; 173 (Suppl):7-11.

[66] Dyck PJ. Detection, characterization and Staging of polyneuropathy: Assessed in Diabetics. Muscle Nerve.1988; 11:21-32.

[67] Dyck PJ, Karnes J, O'Brien PC. Diagnosis, Staging and classification of diabetic neuropathy and association with other complications. In Dyck PJ. Thomas PK, Asbury AK et al (eds). Diabetic Neuropathy. Philadelphia: WB Saunders. 1987: $36-44$.

[68] American Diabetic Association. Clinical Practice Recommendations 1995. Diabetic Care 18:8-15, 1995.

[69] Robinson LR, Stolov WC, Rubner DE, et al. Height is an independent risk factor for neuropathy in diabetic men. Diabetes Res Clin Pract 1992; 16:97-102.

[70] Thomas PK. Metabolic neuropathy. J R Coll Physicians Lond $1973 ; 7: 154-160$

[71] Polydefkis M, Griffin JW, Mcarthur J. New insights into diabetic polyneuropathy. JAMA 2003; 290(10):1371-1376.

[72] Haslbeck KM, Schleicher E, Bierhaus A et al. The AGE/RAGE/NF-(kappa) B pathwaymay contribute to the pathogenesis of polyneuropathy in impaired glucose tolerance (IGT). Exp Clin Endocrinol Diabetes 2005; 113(5):288-291.

[73] Cameron NE, CottorMA. Metabolic and vascular factors in the pathogenesis of diabetic neuropathy. Diabetes 1997; 46(suppl 2):S31-S37.

[74] Danis RP, Bingaman DP, Jirousek M, Yang Y. Inhibition of intraocular neovascularization caused by retina ischemia in pigs by PKC beta inhibition with LY333531. Ophthalmol Vis Sci.1998; 39: 171-179.

[75] Hata Y, Rook SL, Aiello LP. Basic fibroblast growth factor induces expression of VEGF receptor KDR through a protein kinase $\mathrm{C}$ and $\mathrm{p} 44 / \mathrm{p} 42$ mitogen-activated protein kinase-dependant pathway. Diabetes 1999; 48: 1145-1155.

[76] Cameron NE, Cotter MA. Comparison of the effects of ascorbyl $\mu$-linolenic acid and $\mu$-linolenic acid in the correction of neurovascular deficits in diabetic rats. Diabetilogica 1996; 39:1047-1054.

[77] Cameron NE, Cotter MA. Basso M, et al. Comparison of the effects of inhibitors of aldose reductase and sorbitol dehydrogenase on neurovascular function, nerve conduction and tissue polyol pathway metabolites in streptozotocin-diabetic rats. Diabetilogica 1997; 40:271-281. 
[78] Yorek MA, Wiese TJ, Davidson EP, et al. Reduced motor nerve conduction velocity and $\mathrm{Na}(+)-\mathrm{K}(+)$-ATPase activity in rats maintained on L-fructose diet. Reversal by myo-inositol supplementation. Diabetes 1993; 42:1401-1406.

[79] Honing ML, Morrison PJ, Banga JD, et al. Nitric oxide availability in diabetes mellitus. Diabetes Metab Rev 14:241-249, 1998.

[80] Canal N, Nemni R. Autoimmunity and diabetic neuropathy. Clin Neurosci 1997; 4:371-373.

[81] Brownlee M. Biochemistry and Molecular cell biology of diabetic complications. Nature. 2001; 414: 813-820.

[82] Maillard LC. Action des acides amines sur les sucres: formation des melaniodines par voie methodique. C.R. Academy Sciences. 1912; 154: 66-68.

[83] Brownlee M, Aiello LP, Friedman E, Vinik AI, Nesto RW, Boulton AJM. Complications of Diabetes Mellitus. In: Williams Textboot of Endocrinology. 10th ed. 2003 (eds) Larsen R, Krokenberg HM, Melmed S, Polonsky KS. Suunders pp 1560-1563.

[84] Pfeifer MA, Ross D, Schrange J, et al. A highly successful and novel model for the treatment of chronic painful peripheral neuropathy. Diabetes Care 1993; 16:1103-1115.

[85] Sharma KR, Cross J, Farronay O, et al. Demyelinating neuropathy in diabetes mellitus. Arch Neurol 2002; 59:758-765

[86] Beach KW, Bedford GR, Bergelin RO, et al. Progression of lower-extremity arterial occlusive disease in type 2 diabetes mellitus. Diabetes Care 1998; 11:464-472.

[87] Uusitupa MI, Niskanen LK, Siitonen O, et al. 5-year incidence of atherosclerotic vascular disease in relation to general risk factors, insulin level, and abnormalities in lipoprotein composition in non-insulin-dependent diabetic and nondiabetic subjects. Circulation 1990; 82:27-36.

[88] Gadepalli R, Dhawan B, Sreenivas V, et al. A clinico-microbiological study of diabetic foot ulcers in an Indian tertiary care hospital. Diabetes Care. 2006; 29:1727-1732

[89] Zubair M, Malik A, Ahmad J. Study of Plasmid mediated Extended Spectrum Beta Lactamase producing Strains of Enterobacteriaceae, Isolated from Foot Infections in North Indian tertiary care hospital. Diabetes Technology and Therapeutics 2012: 12(4); 315-324.

[90] Premlatha G, Shanthirani S, Deepa R, et al. Prevalence and risk factors of peripheral vascular disease in a selected South Indian populations. Diabetes Care 2000; 23(9): 1295-1300.

[91] Weerasuriya N, Siribaddana S, Dissanayake A, et al. Long-term complications in newly diagnosed Sri Lankan patients with type 2 diabetes mellitus. QJM 1998; 91:439-443.

[92] Melton LJ, Macken KM, Palumbo PJ, et al. Incidence and prevalence of clinical peripheral vascular disease in a population based cohort of diabetic patients. Diabetes Care $1980 ; 3: 650-654$.

[93] Beks PJ, Mackaay AJ, de Neeling JN, de Vries H, Bouter LM, Heine RJ. Peripheral arterial disease in relation to glycaemic level in an elderly Caucasian population: the Hoorn study. Diabetologia. 1995; 38:86 -96.
[94] Federman DG, Trent JT, Froelich CW, et al. Epidemiology of peripheral vascular disease: a predictor of systemic vascular disease. Ostomy Wound Manage 1998; 44:58-62.

[95] Cheng SW, Ting AC, Lau H, et al. Epidemiology of atherosclerotic peripheral arterial occlusive disease in Hong Kong. World J Surg 1999; 23:202-206.

[96] Papademetriou V, Narayan P, Rubins H, et al. Influence of risk factors on peripheral and cerebrovascular disease in men with coronary artery disease, low high density lipoprotein cholesterol levels and desirable low density lipoprotein cholesterol levels: Department of Veterans Affairs HDL Intervention Trial. Am Heart J 1998; 136:734-740.

[97] Katsilambros NL, Tsapogas PC, Arvanitis MP, et al. Risk factors for lower-extremity arterial disease in non-insulin-dependent diabetic persons. Diabet Med 1996; 13:243-246.

[98] Jager A, Kostense PJ, Ruhe HG, et al. Microalbuminuria and peripheral arterial disease are independent predictors of cardiovascular and all-cause mortality, especially among hypertensive subjects: five-year follow-up of the Hoorn Study. Arterioscler Thromb Vasc Biol 1999; 19:617- 624.

[99] Taylor LM Jr, Moneta GL, Sexton GJ, et al. Prospective blinded study of the relationship between plasma homocysteine and progression of symptomatic peripheral arterial disease. J Vasc Surg 1999; 29:8-19.

[100] Wollesen F, Dahlen G, Berglund L, et al. Peripheral atherosclerosis and serum lipoprotein (a) in diabetes. Diabetes Care 1999; 22:93-98.

[101] Kannel WB, D'Agostino RB, Wilson PW, et al. Diabetes, fibrinogen, and risk of cardiovascular disease: the Framingham experience. Am Heart J 1990; 120: 672-676.

[102] Edmonds ME, Blundell MP, Morris ME, et al. Improved survival of the diabetic foot: The role of a specialized foot clinic. Q J Med. 1986; 60(232):763-771.

[103] Veves A, Murray H, Young MJ, et al. Do high foot pressures lead to foot ulcerations?: A prospective study [abstract]. Diabetologia 1991; 34(2):A40.

[104] Stess RM, Jensen SR, Mirmiran R. The role of dynamic planter pressures in diabetic foot ulcers. Diabetes Care 1997; 20(5):855-858.

[105] Murray HJ, Young MJ, Hollis S, et al. The association between callus formation, high pressures and neuropathy in diabetic foot ulceration. Diabet Med 1996; 13 (11):979-982.

[106] Delbridge L, Ellis CS, Robertson K, et al. Nonenzymatic glycosylation of keratin from the stratum corneum of the diabetic foot. British Journal of Dermatology. 1985; 112: 547-554.

[107] Birke IA, Cornwall MW, Jackson M. Relationship between hallux limitus and ulceration of the great toe. Journal of Orthopaedic and Sports Physical Therapy. 1988; 10: 172-176.

[108] Fernando DJS, Masson EA, Veves A, et al. Relationship of limited joint mobility to abnormal foot pressures and diabetic foot ulceration. Diabetes Care. 1991; 14: 8-11.

[109] Hampton G, Birke IA. Treatment of wounds caused by pressure and insensitivity. In: Kloth LC, MeCulloch iM, Feeder iA(eds). Wound healing: alternatives in management. Davis, Philadelphia 1990: 196-220. 
[110] Boyko EJ, Lipsky BA. Infection and diabetes mellitus. In Harris MI (ed): Diabetes in America, 2nd edition. NIH publication No 95-1468. Bethesda, MD: National Institute of Health. 1995, pp 485-499.

[111] Muller LM, Gorter KJ, et al. Increased risk of common infections in patients with type 1 and type 2 diabetes mellitus. Clin Infect Dis 2005; 41(3): 281-288.

[112] Shah BR, Hux JE. Quantifying the risk of infectious diseases for people with diabetes. Diabetes Care 2003; 26 (2): 510-513.

[113] Apelqvist J, Larsson J. What is the most effective way to reduce incidence of amputation in the diabetic foot?. Diabetes Metab. Res. Rev 2000;16:S75-S83.

[114] Anandi C, Alaguraja D, Natarajan V, Ramanathan M, Subramaniam CS, Thulasiram M, Sumithra S. Bacteriology of diabetic foot lesions. Indian Journal of Medical Microbiology 2004; 22(3): 175-178.

[115] Margolis DJ, Allen-Taylor L, Hoffstad O, Berlin JA. Diabetic neuropathic foot ulcers and amputation. Wound Repair Regen. 2005; 13: 230-236.

[116] Lavery LA, Armstrong DG, Wunderlich RP, et al. Risk factors for foot infection in person with diabetes. Diabetes Care 2006; 6: 1288-1293.

[117] Peters EJ, Lavery LA, et al. Diabetic lower extremity infection: Influence of physical, psychological, and social factors. J Diabetes Complications 2005; 19 (2): 107-112.

[118] Pendsey S: Epidemiological aspects of diabetic foot. J Diabetes Develop Countries 1994; 2: 37-38.

[119] Viswanathan V, Jasmine JJ, Snehalatha C, et al. Prevalence of pathogens in diabetic foot infection in south Indian type 2 diabetic patients. JAPI 2002; 50:1013-1016.

[120] Zubair M, Malik A, Ahmad J. Clinico-microbiological study and antimicrobial drug resistance profile of diabetic foot infections in North India. The Foot 2011 (March): 21(1): 6-14.

[121] Bowler PG. Wound pathophysiology, infection and therapeutic options. Ann Med 2002, 34(6): 419-427.

[122] Andrew S. Powlson and Anthony PC. The treatment of diabetic foot infections. J Antimicrob Chemother 2010; 65 (3): 3-9.

[123] Citron DM, Goldstein EJC, Merriam CV, Lipsky BA, Abtamson MA. Bacteriology of moderate-to-severe Diabetic foot infections and in vitro activity of antimicrobial agents. J. Clin Microbio 2006; 45(9):2819-2829.

[124] Ramakant P, Verma AK, Misra R, Prasad KN, Chand G, Mishra A, Agarwal G, Agarwal A, Mishra AK. Changing microbiological profile of pathologenic bacteria in diabetic foot infections: time for a rethink on which empirical therapy to choose?. Diabetologia 2011; 54:58-64.

[125]Zubair M, Malik A, Ahmad J. The impact of creatinine clearance on the outcome of diabetic foot ulcers in North Indian tertiary care Hospital. Diabetes \& Metabolic Syndrome: Clinical Research \& Reviews. 2011; 5(3): 120-125.

[126] Louie TJ, Bartlett JG, Tally FP, Gorbach SL. Aerobic and anaerobic bacteria in diabetic foot ulcers. Ann Intern Med. 1976; 85:461-463.

[127] Sapico FL, Witte JL, Canawati HN, et al. The infected foot of the diabetic patient: quantitative microbiology Guidelines for
Diabetic Foot Infections - CID 2004:39 (1 October) 905 and analysis of clinical features. Rev Infect Dis. 1984; 6(Suppl 1): S171 6 .

[128] Lily SYN, Kwang LL, Yeow SCS, Tan TY. Anaerobic culture of diabetic foot infections: organisms and aantimicrobial susceptibilities. Ann Acad Med Singapore 2008; 37:936-939.

[129] Sapico FL, Canawati HN, Witte JL, et al. Quantitative aerobic and anaerobic bacteriology of infected diabetic feet. J Clin Microbiol. 1980; 12:413-20.

[130] Cooper CR Jr, McGinnis MR,. Arch. Pathol. Lab. Med 1997; $121,798-804$.

[131] Abdulrazak A, Bitar ZI, Al-Shamali AA, and Mobasher LA. Bacteriological study of diabetic foot infections. J. Diabetes Complications 2005; 19:138-141.

[132] Raja NS. Microbiology of diabetic foot infections in a teaching hospital in Malaysia: a retrospective study of 194 cases. J Microbiol Immuno Infect 2007; 40(1):39-44

[133] Armstrong DG, Joseph WS, Lavery L, et al. Treating MRSA infections. Experts share their insights on diagnosis and treatment. Wounds 2004; S1-S23.

[134] Bridges RM, Deitch EA. Diabetic foot infections: Pathophysiology and treatment. Surg Clin North Am 1994, 74: 537-555.

[135] Bendy RH, Nuccio PA, Wolfe E, et al. Relationship of quantitative wound bacterial counts to healing of decubiti. Effect of topical gentamicin. Antimicrobial Agents and Chemotherapy $1964 ; 4,147-55$.

[136] American Diabetes Association. Consensus development conference on diabetic foot wound care. Diabetes Care 1999; $22,1354-60$.

[137] Gardner SE, Frantz RA \& Doebbeling BN. The validity of the clinical signs and symptoms used to identify localized chronic wound infection. Wound Repair and Regeneration. 2001; 9: $178-86$.

[138] Tice A, Hoaglund P, Giani G, et al. Outcomrs of osteomyelitis among patients treated with outpatient parenteral antimicrobial therapy. Am J Med 2003; 114(9): 723-728.

[139] Lipsky BA, McDonald D, Litka PA. Treatment of infected diabetic foot ulcers: Topical MSI-78 vs. oral ofloxacin (abstract) Diabetologia 1997; 40(1): 482.

[140] Raymakers JT, Houben AJ, et al. The effect of diabetes and severe ischaemia on the penetration of ceftazidime into tissues of the limb. Diabetic Medicine 2001; 18(3): 229-234.

[141] Armstrong DG, Stephan KT, Joseph, et al. What is the shelf -life of physician- mixed antibiotic-impregnated calcium sulphate pellets? J Foot Ankle Surg 2003, 42(5): 302-304.

[142] Lipsky BA, Pecoraro RE, Larson SA, et al. Outpatient management of uncomplicated lower-extremity infections in diabetic patients. Arch. Intern. Med. 1990; 150: 790-797.

[143] Van Damme H, Rorive M, Lavery LA, et al. Amputations in diabetic patients: A plea for footsparing surgery. Acta chir Belg 2001; 101(3): 123-129.

[144] Rauwerda JA. Surgical treatrment of the infected diabetic foot. Diabetes Metab Rs Rev2004, 20(1): S41-S44. 
[145] Tan JS, Friedman NM, Hazelton-Miller C, et al. Can aggressive treatment of diabetic foot infection reduce the need for above-ankle amputation? Clin Infect Dis 1996; 23: 286-291.

[146] Abbott CA, Boyko EJ. Diabetes related comorbidities in Asian Americans: results of a national health Survey. J Diabetes Complications 19(2); 101-106: 2005.

[147] Centres for Disease Control and Prevention: History of foot ulcer among persons with diabetes: United States, 2000-2002, MMWR Morb Mortal Wkly Rep 2003; 52(45):1098-1103,.

[148] Muller IS, De Grauw WJ, Van Gerwen WH, et al. Foot ulceration and lower limb amputation in type 2 diabetic patients in Dutuch primary health care. Diabetes Care 2002; 25(3):570-574.

[149] Ramsey SD, Newton K, Blough D, et al. Incidence, outcomes, and cost of foot ulcers in patients with diabetes. Diabetics Care 1999; 22:382-387.

[150] Abbott CA, Vileikyte L, Williamson S, et al., Multicentric study of the incidence of and predictive risk factors for diabetic neuropathic foot ulceration. Diabetes care 1998; 21: 1071-1075.

[151] Boyko EJ, Ahroni JH, Cohen V, et al., Prediction of diabetic foot occurance using commonly available clinical information: The Seattle Diabetic Foot Study. Diabetes Care 2006; 29(6): 1202-1207.

[152] Carrington AL, Shaw JE, Van Schie CH, et al. Can motor nerve conduction velocity predict foot problems in diabetic subjects over a 6-year outcome period? Diabetes Care 25(11):2010-2015, 2002.

[153] Litzelaman DK, Slemenda CW, Langefeld CD, et al. Reduction of lower extremity clinical abnormalities in patients with non-insulin dependant diabetes mellitus: A randomized, controlled trial. Ann Intern Med 1993; 19(1): 36-41.
[154] Chaturvedi N, Stevens LK, Fuller JH, et al. Risk factors, ethnic difference and mortality associated with lower extremity gangrene and amputation in diabetes. Diabetiologica 2001; 44(suppl 2):S65-S71.

[155] Humphrey ARG, Dowse GK, Thomas K, et al. Diabetes and nontraumatic lower extremity amputations: incidence, risk factors and prevention: 12-year follow- up study in Nauru. Diabetes Care. 1996; 19:710-714.

[156] Humphrey LL, Palumbo PJ, Butters MA, et al. The contribution of non-insulin dependent diabetes to lower extremity amputation in the community. Arch. Intern. Med.1994; 154:885-892.

[157] Lehto S, Pyorala K, Ronnemaa T, et al. Risk fators predicting lower extremity amputation in NIDDM. Diabetes Care 1996; 19(6):607-612.

[158] Morris AD, McAlpine R, Steinke D, et al. Diabetes and lower limb amputation in the community. Diabetes Care 1998; 21:738-743.

[159] Siitonen OL, Niskanen LK, Laakso M, et al. Lower extremity amputation in diabetic and nondiabetic patients. Diabetes Care 1993; 16:16-20.

[160] Trautner C, Hasstert B, Giani G, et al. Incidence of lower limb amputations and diabetes. Diabetes Care 1996; 19(9): 1006-1009.

[161] Van Houtum W, Lavery LA. Outcomes associated with diabetes-related amputations in the Netherlands and in the state of California. J Int Med 1996; 240:227-231.

[162] Hennis AJJ, Fraser HS, Jonnalagadda R, et al. Explanations for the high risk of diabetes-related amputation in a Carribean population of black African descent and potential for prevention. Diabetes Care 2004; 27(11):2636-2641. 